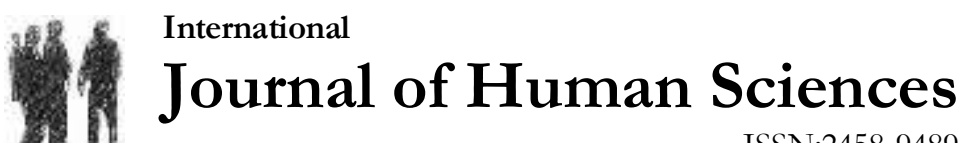 \\ ISSN:2458-9489
}

Volume 14 Issue 3 Year: 2017

\section{The relationship between social network usage and some personality traits}

\author{
Asena Y1maz ${ }^{1}$ \\ Mehmet Bilgin ${ }^{2}$
}

\begin{abstract}
The aim of the research, is to examine the relationship between adolescents' five-factor personality features by use of Social Media. As for sample, there are 548 girl and 441 boy students and they are between the ages of 11-18. Adolescents' data participating in the study, are determined by Big Five Factor personality traits Scale. Prepared data on the use of social media called "Personal Information Form" has been obtained by researcher. In the analysis of data, understanding of social media use times whether it differs according to big five personality traits, According to the social media using time, there was no significant difference between the agreeableness and openness subscales. On the other hand, there is a significant differences between conscientiousness, extraversion and neuroticism. In association with five personality traits of social media purpose, it was found that there are significant differences with different personality traits for each purpose.
\end{abstract}

Keywords: Five Factor Personality Traits; Social Media; Social Networks; Duration of use; Adolescent;

\section{INTRODUCTION}

With the advances in technology, significant changes and transformations were observed in the lifestyles of individuals and the structures of societies. In the age of information that requires learning more and accessing to accurate information, the technology offers new technological tools for learning media, as well as providing the individuals with the opportunity of sharing the real and digital life in different learning and sharing environments. The leading one among these environments is the social networks. Online social network, which is one of the means of social network, is the web-based services providing the individual with the chance of communicating and also the chance of sharing files, photos or information, besides allowing them to construct their own profiles (Boyd and Ellison, 2007).

The style of using the social media differs among the individuals. The expectations of individuals from the social media tools are different, as well as different sorts of use result in different gratifications. The interpersonal differences may sometimes be related with the deprivation that the individual is actually experiencing at that moment. When the deprivation disappears, then the other deprivations, which the personal priorities have identified before, may come into play. Social media is, for some people, the environment, where they avoid from

\footnotetext{
${ }^{1}$ M.A., mbilgin@cu.edu.tr

2 Assoc. Prof. Dr., Çukurova University; mbilgin@cu.edu.tr
} 
Yllmaz, A., \& Bilgin, M. (2017). The relationship between social network usage and some personality traits. Journal of Human Sciences, 14(3), 2219-2243. doi:10.14687/jhs.v14i3.4659

socializing, stay alone with themselves, and become the observer, while it arises as a result of the desire of socialization and being appreciated and followed. But, however, this generally doesn't remain constant, and healthy individuals may exhibit the indications of socialization sometimes and those of avoidance some other times (Hazar, 2011).

Burger (2006) defined the personality as the consistent behavior patterns and internal events arising from the person. While the consistent behavior pattern indicates the exhibition of always same or similar behaviors for the same situations, the intrapersonal processes represent all of our internal emotional, cognitive and motivational processes affecting how we behave and feel. Cüceloğlu (2011) defined the personality as the styles of structured relationships, which the persons establish with their internal and external environments and which are considered by the others as distinguishing and consistent. According to Tutar (2013), the personality is the whole of distinguishing behaviors that are specific to the person. There is no general definition of personality that has gained a general acceptance.

The Five-Factor Model, which is one of the models determining and identifying the fundamental traits of personality, is used as an alternative approach in assessing the personality. The basis for the 5-Factor approach consists of the view that various personality traits that are perceived reflect on the discourses of various cultures in their daily lives, and that the personal difference will be coded with different words in language (Somer, 1998).

Five-Factor Model is widely accepted as a useful classification of personality traits. These factors are neuroticism, openness to development/experience, tendermindedness (adaptability), extroversion, and self-control (McCrae and Costa, 2006). The individuals having high level of extroversion tendency are social, talkative, assertive, and active, while those having low level of extroversion tendency are shy and cautious. On the other hand, the individuals with high level of tendermindedness tendency are calm, submissive, generous, cooperative, and modest, while those having low level of tendermindedness tendency are angry, cruel, and sceptic. Individuals having high level of openness to experience are intellectual, creative, sensible, and open-minded, while those having low level of openness to experience are realist, insensible, and traditionalist. The individuals having high self-control level are conscientious/careful, perfect, responsible, and rigorous, while those having low level of self-control are anxious, depressive, angry, irregular, and untidy. The individuals having high level of neuroticism tendency are anxious, depressive, angry and distrustful, while those having low level of neuroticism tendency are calm, self-esteem, and emotionally balanced (Roccas, Sagiv, Schwartz and Knafo, 2002).

The social networks websites that are seen as new tools for personality and identity formation provide the individuals with chance to express themselves (Mehdizadeh, 2010). The social networks allowing the persons to freely define and express themselves are used by the users for various purposes. These purposes vary between the individuals, as well as the duration of use and the network websites being used also vary.

Social networking websites are a very popular way of online communication among the adolescents (Subrahmanyam, Reich, Waechter and Espinoza, 2008). The internet and social networking sites, which offered large opportunities in terms of use and access to the information in recent years, come to the forefront as a tool for wide socialization, and this offers new dimensions for the interpersonal interaction methods, as well as the cultural lives (Subrahmanyam and Greenfield, 2008; Özmen, Aküzüm, Sünkür and Baysal, 2011).

In different studies carried out on the social network use of adolescents, the rate of social network use was found to be $55 \%$ by Lenhart and Madden, (2007), 78\% by Subrahmanyam et al. (2008) and Pempek, Yermolayeva and Calvert, (2009), 90.5\% by Kim and Davis, (2009), 73\% by Lenhart, Purcell, Smith and Zickuhr, (2010), 66\% by Bayhan (2011), and 89\% by Alican and Saban (2013). More recent studies carried out by Akyaz1 and Tutgun Ünal, (2013), Hazar, (2011), Tutgun Ünal and Köroğlu, (2013), and Otrar and Argin (2014) reported that this rate approached to 90\%.

Subrahmanyam et al. (2008) have reported that $25 \%$ of the users visit social network sites for several times a day. Moreover, in the same study, it was reported that, of the participants, $36 \%$ 
Yllmaz, A., \& Bilgin, M. (2017). The relationship between social network usage and some personality traits. Journal of Human Sciences, 14(3), 2219-2243. doi:10.14687/jhs.v14i3.4659

spent half an hour of less on social network sites, $18 \%$ spend an hour, and $10 \%$ spent more than 2 or 3 hours a day. It has also been reported that $68.9 \%$ of participants spent less than 1 hour a day (Kim and Davis, 2009).

Individuals use social networks for various purposes. Although the intended purpose of the users vary between the sites, these purposes can be exampled with communicating with family and friends (Boyd and Ellison, 2007), access to the information (Park and Kim, 2013), entertainment (Lin, Hoffman and Borengasser, 2013), access to friends, sharing the private life, and introducing oneself to unknown persons (Ylldırım and Özmen, 2011), maintaining the communication with friends, spending time, downloading files, and search for knowledge (Kim and Davis, 2009), revealing and realizing the identity (Livingstone, 2008), keeping in touch with friends, meeting with new people, sharing information, exploring one's own identity, receiving knowledge (Davies and Cranston, 2008), social interaction, communication, education, knowing, being recognized (Tanrıverdi and Sağır, 2014), commenting, written, visual and musical information (Balaman and Karataş, 2012), and chatting with friends, following the posts on favorite sites, following friends, and sharing the knowledge (Akca Baştürk, 2014).

Nowadays, the communication between the young individuals is mainly mediated by the social network sites, and these social network sites draw gradually increasing attention of young population (Ahn, 2011). The rate of the use of social network sites by the adolescents were reported to be 55\% for MySpace/Facebook (Lenhart and Madden, 2007), 66\% for Facebook (Bayhan, 2011), 89\% for Facebook, 57\% for YouTube and Instagram, 45\% for Twitter (Youth and Social Media Research, 2013), 71.8\% for Facebook, 13.3\% for Twitter, and 11.3\% for YouTube (Otrar and Argin, 2014).

Given the studies on social networks and personality traits, the positive correlation was reported between the use of social media and extroversion and openness for improvement, while negative correlation was reported between the social networks and neuroticism (Correa, Hinsley and Züniga, 2010). It was revealed that the users of Facebook had higher levels of the personality traits "extroversion" and "neuroticism", while the Twitter users were open to experience more than Facebook users were (Hughes, Rowe, Batey and Lee, 2012). It was found that the individuals having higher scores in "extroversion" personality trait spent more time in Facebook (Glass, Prichard, Lafortune and Schwab, 2013). Positive relationships were observed between the information used for defining profile and the extroversion and between the photos shared/added and the scores in extroversion (Gosling, Augustine, Vazire, Holtzman and Gaddis, 2011). The extroversive individuals were observed to tend to use Facebook more than introversive individuals did (Ryan and Xenos, 2011). The extroversion was found to be in positive relationship with having more friends, commenting, posting photos of oneself, and using the status updates, while it has negative relationship with playing game (Wang, Jackson, Zhang and Su, 2012). It was determined that the Twitter users having attracting user profile had more extroversive and emotionally balanced personality (Quercia, Kosinski, Stillwell and Crowcroft, 2011) when compared to other users.

Increasing use of the social media, gradually increasing number of users, and its transformation into almost irreplaceable component of daily life indicate that social media is a subject that needs to be investigated. Proliferation of use of social media among the secondary school and high school students necessitates the studies on this population segment. Moreover, the studies on personality traits and use of social media indicated the relationship between these parameters. For this reason, in this study, it was aimed to investigate the relationship between students' use of social media and their personality traits.

In this study, effects of the use of social media on the personality traits were examined on the adolescent sample. In present paper, the time, which the adolescents spent on social media, and if the variables such as their purpose of using social networks affected the social media accounts, which they used, varied by the personality traits of adolescents are examined. 


\section{Research Model}

\section{METHOD}

In order to determine the relationship between the adolescents' use of social networks and their Five-Factor Inventory personality traits, the comparison-type, relational screening model descriptive research was employed. The independent variables of present study are mean time spent on social media, purposes of using social media, and social media accounts, while the dependent variables are tendermindedness, self-control, neuroticism, extroversion, and openness for improvement.

\section{Sample}

The sample of present study was established via stratified sampling method. The stratified sampling method allows the presentation of sub-groups in harmony with their portions in the universe (Büyüköztürk, Çakmak, Akgün, Demirel and Karadeniz, 2008). Using the stratified sampling method, the schools were chosen based on three different socioeconomic segments (low, medium, and high). After selecting the schools, the classes and students to be employed were determined using random sampling method. Of the students participating into the sample, $55.4 \%$ (548) were girls and $44.6 \%$ (441) were boys. $20.2 \%$ (200) of the students were in 11-13 age group, $35.9 \%$ (355) in 14-15 age group, and 43.9\% (434) in 16-18 age group.

The highest level of time spent on social networks was found to be $1-3$ hours by $39.9 \%$ (395), less than 1 hour with by $30.6 \%$ (303), 3-5 hours by $17.8 \%$ (176), more than 7 hours by $6.2 \%$ (61), and 5-7 hours by 5.5\% (54).

Given the adolescents' purposes of using social networks, the most frequent purpose was found to be communicating with friends by $63.3 \%$ (626), followed by getting information by $62.9 \%$ (622), recreational purposes by $60.1 \%$ (594), online chatting by $51.5 \%$ (509), and sharing photos by $39.4 \%$ (390). These are followed by playing games by 33.8\% (334), checking with friends by $31.3 \%$ (310), commenting by $19.9 \%$ (197), having new friends by $18.3 \%$ (181), sharing videos by $15.9 \%$ (157), and sharing news by $15.3 \%$ (151).

Adolescents uses most frequently Facebook by 76.5\% (757), followed by WhatsApp by $73.0 \%$ (722), Instagram by 59.2\% (585), Google+ by 58.0\% (574), and YouTube by $57.9 \%$ (573). These are followed by Twitter with the portion of 34.6\% (342), Skype with the portion of 31.6\% (313), Vine with the portion of $21.4 \%$ (212), Tumblr with the portion of $16.2 \%$ (160), Foursquare with the portion of $9.1 \%$ (90), BlogSpot with the portion of $4.6 \%$ (45), and Pinterest with the portion of $3.5 \%$ (35).

\section{Data Collection Tools}

Five-Factor Inventory Scale: (The Five-Factor Inventory, BFI): The Five-Factor Inventory was developed by John, Donahue and Kentle (1991), and is a short tool measuring the prototypic elements of five factors. Despite the fact that it has 6 sub-scales including 10-18 items in each, it involves the items that well represent both of the good psychometric characteristics and the subscales (John and Srivastava, 1999). The 5-Point Likert-type scale has 8 items in "Extroversion" subscale, 9 items in "Tendermindedness/Adaptability" subscale, 9 items in "Selfcontrol/Responsibility" subscale, 8 items in "Neuroticism" subscale, and 10 items in "Openness to experience", totally 44 items. The $2^{\text {nd }}, 6^{\text {th }}, 8^{\text {th }}, 9^{\text {th }}, 12^{\text {th }}, 18^{\text {th }}, 21^{\text {st }}, 23^{\text {td }}, 24^{\text {th }}, 27$ th $, 21^{\text {st }}, 34^{\text {th }}, 41^{\text {st }}$, and $43^{\text {rd }}$ items are graded inversely (John and Srivastava, 1999).

The adaptation of scale into Turkish was performed by Sümer and Sümer (2005) within the scope of a study carried out on self-description profiles and patterns in 56 countries (Schmitt, Allik, McCrae and Benet-Martinez, 2007). The Cronbach's Alpha coefficients of the scale were reported to vary between .66 and .77 by Sümer, Lajunen and Özkan (2005).

The reason for choosing Five-Factor Inventory for this study is that its reliability and validity were shown from intercultural aspect. In mentioned study, the Cronbach's Alpha coefficient values of this scale were calculated to be .79, .77, .76, .70 and .78, in terms of 
Yllmaz, A., \& Bilgin, M. (2017). The relationship between social network usage and some personality traits. Journal of Human Sciences, 14(3), 2219-2243. doi:10.14687/jhs.v14i3.4659

neuroticism, extroversion, openness for improvement, a adaptability, and self-control, respectively (Schmitt et al., 2007).

John and Srivastava (1999) have reported the Cronbach's Alpha coefficient of this inventory to vary between .75 and .90 , as well as these coefficients were found to vary between .80 and .90 in measurements performed 3 months later. On the other hand, Fossati, Borroni, Marchione and Maffei (2011) have reported the Cronbach's Alpha coefficient to vary between .77 and .81 , as well as it varied between .75 and .86 in re-test reliability results found 2 months later.

\section{RESULTS}

In this section, the ANOVA and MANOVA findings obtained from statistical analyses are presented. For this purpose, the total scores of subscales of Five-Factor Inventory filled by the adolescents were calculated, and X and SS values of each of the subscales were computed. Then, the adolescents' time of using social networks and Five-Factor Inventory were subjected to ANOVA, while the purpose of using social media and social network accounts and Five-Factor Inventory were subjected to MANOVA.

\section{Is there a statistically significant difference between Five-Factor personality traits by the times of using social networks and the mean scores from?}

The X and SS values of Five-Factor Inventory personality traits by the adolescents' time of using social networks are presented in Table 1.

Table 1. Arithmetical Mean and Standard Deviation Values of Adolescents' Time of Using Social Networks by Five-Factor personality Traits

\begin{tabular}{ccccccccccc}
\hline Time & $\begin{array}{c}\text { Less than 1 } \\
\text { hour }\end{array}$ & & 1-3 Hours & 3-5 Hours & 5-7 Hours & \multicolumn{2}{c}{$\begin{array}{c}\text { 7 Hours } \\
\text { and longer }\end{array}$} \\
\hline Personality Traits & $\mathrm{X}$ & SS & $\mathrm{X}$ & SS & X & SS & X & SS & X & SS \\
\hline Tendermindedness & 32.47 & 5.12 & 32.16 & 4.94 & 31.33 & 5.18 & 31.38 & 5.62 & 31.00 & 4.51 \\
\hline Self-control & 32.93 & 5.83 & 31.89 & 5.48 & 30.58 & 5.64 & 28.74 & 4.79 & 28.42 & 6.54 \\
\hline Neuroticism & 23.34 & 5.67 & 24.11 & 5.59 & 24.69 & 6.20 & 27.18 & 5.32 & 25.55 & 4.75 \\
\hline $\begin{array}{c}\text { Openness for } \\
\text { improvement }\end{array}$ & 35.30 & 5.89 & 35.91 & 5.84 & 36.77 & 5.82 & 36.29 & 6.37 & 35.73 & 5.98 \\
\hline Extroversion & 26.28 & 4.74 & 26.79 & 4.72 & 27.61 & 4.69 & 27.59 & 4.90 & 27.32 & 4.85 \\
\hline
\end{tabular}

Given Table 1, it can be seen that, in tendermindedness parameter, X equals to 32.47 for "Less than 1 hour", while X equals to 32.83 for "Less than 1 hour" in "Self-control", to 25.55 for "5-5 Hours" in "Neuroticism" personality trait, to 36.77 for "3-5 Hours" in "Openness for improvement", and to 27.61 for "3-5 Hours" in of "Extroversion".

Single-factor ANOVA results regarding the mean scores in Five-Factor personality traits by the time of using social networks are presented in Table 2.

Table 2. ANOV A Results of Adolescents' Time of Using Social Networks by Five-Factor personality Traits

\begin{tabular}{llccccc}
\hline \multirow{5}{*}{ Tendermindedness } & $\begin{array}{c}\text { Sum of } \\
\text { Squares }\end{array}$ & Df & $\begin{array}{c}\text { Mean of } \\
\text { squares }\end{array}$ & F & P \\
& Intergroup & 237.741 & 4 & 59.435 & 2.32 & .055 \\
& Intragroup & 25203.250 & 984 & 25.613 & & \\
& Total & 25440.991 & 988 & & & \\
\hline Self-control & Intergroup & 1810.375 & 4 & 452.594 & 14.12 & .000 \\
& Intragroup & 31524.224 & 984 & 32.037 & & \\
& Total & 33334.599 & 988 & & & \\
\hline
\end{tabular}


Yilmaz, A., \& Bilgin, M. (2017). The relationship between social network usage and some personality traits. Journal of Human Sciences, 14(3), 2219-2243. doi:10.14687/jhs.v14i3.4659

\begin{tabular}{|c|c|c|c|c|c|c|}
\hline Neuroticism & $\begin{array}{l}\text { Intergroup } \\
\text { Intragroup } \\
\text { Total }\end{array}$ & $\begin{array}{c}861.022 \\
31643.184 \\
32504.206\end{array}$ & $\begin{array}{c}4 \\
984 \\
988\end{array}$ & $\begin{array}{c}215.256 \\
32.158\end{array}$ & 6.69 & .000 \\
\hline Openness & Intergroup & 253.102 & 4 & 63.276 & 1.82 & .122 \\
\hline & $\begin{array}{l}\text { Intragroup } \\
\text { Total }\end{array}$ & $\begin{array}{l}34177.885 \\
34430.987\end{array}$ & $\begin{array}{l}984 \\
988\end{array}$ & 34.734 & & \\
\hline Extroversion & $\begin{array}{l}\text { Intergroup } \\
\text { Intragroup } \\
\text { Total }\end{array}$ & $\begin{array}{c}245.936 \\
22143.362 \\
22389.298\end{array}$ & $\begin{array}{c}4 \\
984 \\
988\end{array}$ & $\begin{array}{l}61.484 \\
22.503\end{array}$ & 2.73 & .028 \\
\hline
\end{tabular}

Single factor ANOVA was implemented in order to determine if there is statistically significant difference between the Five-Factor Inventory personality traits scales' $\mathrm{X}$ scores in terms of the times of adolescents' time of using social networks. The results are presented in Table 2.

Given Table 2, the significant differences were found between self-control ( $\mathrm{F}=14.12$, $\mathrm{p}<0.5)$, neuroticism $(\mathrm{F}=6.69, \mathrm{p}<0.5)$ and extroversion $(\mathrm{F}=2.73, \mathrm{p}<0.5)$ by the duration of using social networks. In order to find the source of difference in self-control, neuroticism and extroversion subscales in terms of duration of using social networks, the Tukey test was employed. According to the result of Tukey test, the statistically significant $(\mathrm{p}<0.005)$ relationship in subscale of self-control between the use of social network for less than 1 hour $(X=32.93), 3-5$ hours $(X=30.58), 5-7$ hours $(X=28.74)$ and 7 hours and longer $(X=28.42)$ on behalf of the use of less than 1 hour. Between 1-3 hours $(X=31.89), 5-7$ hours $(X=28.74)$ and 7 hours and longer $(X=$ 28.42) use of social network, statistically significant difference was found on behalf of social network use for $1-3$ hours $(p<.005)$. In neuroticism subscale, the statistically significant $(p<.005)$ difference on behalf of use for less than 1 hour was found between social network use for less than 1 hour $(X=23.34), 5-7$ hours $(X=27.18)$ and 7 hours and longer $(X=25.55)$. Between 1-3 hours $(X=24.11)$ and 5-7 hours $(X=27.18)$ use of social network, a statistically significant relationship against the use for $1-3$ hours $(\mathrm{p}<.005)$ was found. Between 3-5 hours $(X=24.69)$ and 5-7 hours $(X=$ 27.18) use of social network, statistically significant relationship against the use for 3-5 hours was found $(p<.005)$. In extroversion subscale, the statistically significant difference $(p<.005)$ against the use of social network for less than 1 hour was found between the uses for less than 1 hour $(X=$ 26.28) and 3-5 hours ( $\mathrm{X}=27.61)$.

\section{Is There Statistically Significant Difference between Mean Scores of Five-Factor Inventory by the Purposes for Using Social Networks?}

The results of MANOVA, which was applied to Five-Factor Inventory of adolescents, indicate differences in purposes of finding new friends (Wilks Lambda $=.989, \mathrm{~F}(1,987)=2.10$, $\mathrm{p}<0.5$ ), chatting online (Wilks Lambda=.959, $\mathrm{F}(1,987)=8.30, \mathrm{p}<0.5$ ), sharing photos (Wilks Lambda $=.955, \mathrm{~F}(1,987)=9.24, \mathrm{p}<0.5)$, commenting (Wilks Lambda=.976, $\mathrm{F}(1,987)=4.77, \mathrm{p}<0.5)$, accessing to the information (Wilks Lambda $=.979, \mathrm{~F}(1,987)=4.31, \mathrm{p}<0.5$ ), sharing videos (Wilks Lambda $=.988, F(1,987)=2.47, \mathrm{p}<0.5)$, sharing news (Wilks Lambda $=.982, \mathrm{~F}(1,987)=3.56, \mathrm{p}<0.5$ ), playing games (Wilks Lambda $=.962, \mathrm{~F}(1,987)=7.82, \mathrm{p}<0.5$ ), communicating with friends (Wilks Lambda $=.984, \mathrm{~F}(1,987)=3.11, \mathrm{p}<0.5)$, checking what friends are doing (Wilks Lambda $=.934, \mathrm{~F}(1$, $987)=13.87, \mathrm{p}<0.5$ ), and recreation (Wilks Lambda $=.957, \mathrm{~F}(1,987)=8.82, \mathrm{p}<0.5$ ) by the FiveFactor Inventory personality traits scale. These findings indicate that the scores to be obtained from the linear element consisting of Five-Factor personality traits of adolescent vary depending on the purpose of using social network. The results of one-way MANOVA applied to the mean and standard deviation values of adolescents' Five-Factor personality traits are presented in Table 3. 
2225

Yllmaz, A., \& Bilgin, M. (2017). The relationship between social network usage and some personality traits. Joumal of Human Sciences, 14(3), 2219-2243. doi:10.14687/jhs.v14i3.4659

Table 3

Mean Scores, Standard Deviation and MANOVA Results of Adolescents' Purpose for Using Social Network by Five-Factor personality Traits

\begin{tabular}{|c|c|c|c|c|c|c|c|c|c|c|c|c|c|c|c|c|c|c|c|c|c|c|}
\hline $\begin{array}{l}\text { Personality } \\
\text { Traits }\end{array}$ & & Number & Tende & minde & ness & & Self-co & & & & Neuro & cism & & & Openn & is for & prover & & Extror & sion & & \\
\hline $\begin{array}{l}\text { Purposes } \\
\text { Use }\end{array}$ & of & $\mathrm{N}$ & $\mathrm{X}$ & S & F & $\mathrm{P}$ & $\mathrm{X}$ & S & F & $\mathrm{P}$ & $\mathrm{X}$ & $\mathrm{S}$ & $\mathrm{F}$ & $\mathrm{P}$ & $\mathrm{X}$ & $\mathrm{S}$ & $\mathrm{F}$ & $\mathrm{P}$ & $\mathrm{X}$ & $\mathrm{S}$ & F & $\mathrm{P}$ \\
\hline $\begin{array}{l}\text { Finding } \\
\text { New } \\
\text { Friends }\end{array}$ & $\begin{array}{l}\mathrm{Y} \\
\mathrm{N}\end{array}$ & $\begin{array}{l}181 \\
808\end{array}$ & $\begin{array}{l}31.5 \\
32.09\end{array}$ & $\begin{array}{l}5.28 \\
5.02\end{array}$ & 1.57 & .210 & $\begin{array}{l}30.62 \\
31.80\end{array}$ & $\begin{array}{l}6.00 \\
5.74\end{array}$ & 6.13 & $.013 *$ & $\begin{array}{l}24.01 \\
24.28\end{array}$ & $\begin{array}{l}4.82 \\
5.92\end{array}$ & .335 & .563 & $\begin{array}{l}35.94 \\
35.87\end{array}$ & $\begin{array}{l}5.80 \\
6.35\end{array}$ & .019 & .890 & $\begin{array}{l}27.20 \\
26.78\end{array}$ & $\begin{array}{l}4.78 \\
4.75\end{array}$ & 1.14 & .285 \\
\hline $\begin{array}{l}\text { Chatting } \\
\text { Online }\end{array}$ & $\begin{array}{l}\mathrm{Y} \\
\mathrm{N}\end{array}$ & $\begin{array}{l}509 \\
480\end{array}$ & $\begin{array}{l}32.00 \\
31.99\end{array}$ & $\begin{array}{l}5.10 \\
5.04\end{array}$ & 1.57 & $.001 *$ & $\begin{array}{l}31.05 \\
32.16\end{array}$ & $\begin{array}{l}5.84 \\
5.71\end{array}$ & 9.22 & $.002 *$ & $\begin{array}{l}24.52 \\
23.93\end{array}$ & $\begin{array}{l}5.84 \\
5.60\end{array}$ & 2.62 & .105 & $\begin{array}{l}35.36 \\
35.87\end{array}$ & $\begin{array}{l}6.12 \\
5.61\end{array}$ & 7.37 & $.007^{*}$ & $\begin{array}{l}27.53 \\
26.14\end{array}$ & $\begin{array}{l}4.68 \\
4.74\end{array}$ & 21.14 & $.000^{*}$ \\
\hline $\begin{array}{l}\text { Sharing } \\
\text { Photos }\end{array}$ & $\begin{array}{l}\mathrm{Y} \\
\mathrm{N}\end{array}$ & $\begin{array}{l}390 \\
599\end{array}$ & $\begin{array}{l}31.98 \\
32.00 \\
\end{array}$ & $\begin{array}{l}5.21 \\
4.98 \\
\end{array}$ & .004 & .951 & $\begin{array}{l}31.19 \\
31.85\end{array}$ & $\begin{array}{l}5.93 \\
5.71\end{array}$ & 3.03 & .082 & $\begin{array}{l}25.20 \\
23.61\end{array}$ & $\begin{array}{l}5.66 \\
5.71\end{array}$ & 18.46 & $.000 *$ & $\begin{array}{l}36.29 \\
35.62\end{array}$ & $\begin{array}{l}6.06 \\
5.78\end{array}$ & 3.03 & .082 & $\begin{array}{l}27.70 \\
26.31\end{array}$ & $\begin{array}{l}4.56 \\
4.80 \\
\end{array}$ & 20.70 & $.000^{*}$ \\
\hline Commenting & $\begin{array}{l}\mathrm{Y} \\
\mathrm{N}\end{array}$ & $\begin{array}{l}197 \\
792 \\
\end{array}$ & $\begin{array}{l}31.97 \\
32.00 \\
\end{array}$ & $\begin{array}{l}4.95 \\
5.10 \\
\end{array}$ & .005 & .945 & $\begin{array}{l}30.50 \\
31.86 \\
\end{array}$ & $\begin{array}{l}6.37 \\
5.63 \\
\end{array}$ & 8.66 & $.003 *$ & $\begin{array}{l}24.69 \\
24.12 \\
\end{array}$ & $\begin{array}{l}5.38 \\
5.81\end{array}$ & 1.52 & .218 & $\begin{array}{l}36.18 \\
35.81 \\
\end{array}$ & $\begin{array}{l}6.00 \\
5.87\end{array}$ & .606 & .437 & $\begin{array}{l}27.83 \\
26.61 \\
\end{array}$ & $\begin{array}{l}4.61 \\
4.76 \\
\end{array}$ & 10.42 & $.001 *$ \\
\hline $\begin{array}{l}\text { Getting } \\
\text { Informa. }\end{array}$ & $\begin{array}{l}\mathrm{Y} \\
\mathrm{N}\end{array}$ & $\begin{array}{l}622 \\
367\end{array}$ & $\begin{array}{l}32.15 \\
31.73 \\
\end{array}$ & $\begin{array}{l}5.00 \\
5.19 \\
\end{array}$ & 1.54 & .214 & $\begin{array}{l}31.93 \\
31.00 \\
\end{array}$ & $\begin{array}{l}5.79 \\
5.78\end{array}$ & 5.95 & $.015^{*}$ & $\begin{array}{l}23.99 \\
24.66\end{array}$ & $\begin{array}{l}5.74 \\
5.70\end{array}$ & 3.17 & .075 & $\begin{array}{l}36.18 \\
36.47 \\
\end{array}$ & $\begin{array}{l}6.00 \\
5.78 \\
\end{array}$ & 16.59 & $.000 *$ & $\begin{array}{l}27.12 \\
26.41\end{array}$ & $\begin{array}{l}4.67 \\
4.88 \\
\end{array}$ & 5.19 & $.023 *$ \\
\hline $\begin{array}{l}\text { Sharing } \\
\text { Videos }\end{array}$ & $\begin{array}{l}\mathrm{Y} \\
\mathrm{N}\end{array}$ & $\begin{array}{l}157 \\
832\end{array}$ & $\begin{array}{l}31.89 \\
32.01 \\
\end{array}$ & $\begin{array}{l}4.87 \\
5.11\end{array}$ & .071 & .790 & $\begin{array}{l}30.57 \\
31.78 \\
\end{array}$ & $\begin{array}{l}6.03 \\
5.74 \\
\end{array}$ & 5.71 & $.017 *$ & $\begin{array}{l}24.55 \\
24.18 \\
\end{array}$ & $\begin{array}{l}5.05 \\
5.85 \\
\end{array}$ & .561 & .454 & $\begin{array}{l}36.16 \\
35.83 \\
\end{array}$ & $\begin{array}{l}6.09 \\
5.86\end{array}$ & .407 & .524 & $\begin{array}{l}27.60 \\
26.72 \\
\end{array}$ & $\begin{array}{l}4.73 \\
4.75 \\
\end{array}$ & 4.55 & $.033 *$ \\
\hline $\begin{array}{l}\text { Sharing } \\
\text { News }\end{array}$ & $\begin{array}{l}\mathrm{Y} \\
\mathrm{N}\end{array}$ & $\begin{array}{l}151 \\
838 \\
\end{array}$ & $\begin{array}{l}32.29 \\
31.94 \\
\end{array}$ & $\begin{array}{l}5.01 \\
5.08 \\
\end{array}$ & .600 & .439 & $\begin{array}{l}31.76 \\
31.56 \\
\end{array}$ & $\begin{array}{l}5.74 \\
5.83 \\
\end{array}$ & .149 & .700 & $\begin{array}{l}23.94 \\
24.29 \\
\end{array}$ & $\begin{array}{l}5.21 \\
5.82 \\
\end{array}$ & .464 & .496 & $\begin{array}{l}37.31 \\
35.63 \\
\end{array}$ & $\begin{array}{l}5.47 \\
5.94 \\
\end{array}$ & 10.43 & $.001 *$ & $\begin{array}{l}26.63 \\
28.09\end{array}$ & $\begin{array}{l}4.79 \\
4.35\end{array}$ & 12.16 & $.001 *$ \\
\hline $\begin{array}{l}\text { Playing } \\
\text { Games } \\
\end{array}$ & $\begin{array}{l}\mathrm{Y} \\
\mathrm{N}\end{array}$ & $\begin{array}{l}334 \\
655 \\
\end{array}$ & $\begin{array}{l}32.11 \\
31.93 \\
\end{array}$ & $\begin{array}{l}4.96 \\
5.12 \\
\end{array}$ & .281 & .596 & $\begin{array}{l}30.89 \\
31.94 \\
\end{array}$ & $\begin{array}{l}5.99 \\
5.68 \\
\end{array}$ & 7.33 & $.007 *$ & $\begin{array}{l}23.18 \\
24.77 \\
\end{array}$ & $\begin{array}{l}5.30 \\
5.87 \\
\end{array}$ & 17.31 & $.000 *$ & $\begin{array}{l}36.06 \\
35.79 \\
\end{array}$ & $\begin{array}{l}5.97 \\
5.87 \\
\end{array}$ & .464 & .496 & $\begin{array}{l}26.77 \\
26.90 \\
\end{array}$ & $\begin{array}{l}4.66 \\
4.81 \\
\end{array}$ & .157 & .692 \\
\hline $\begin{array}{l}\text { Communic } \\
\text { ating with } \\
\text { Friends }\end{array}$ & $\begin{array}{l}\mathrm{Y} \\
\mathrm{N}\end{array}$ & $\begin{array}{l}626 \\
363\end{array}$ & $\begin{array}{l}32.25 \\
31.55\end{array}$ & $\begin{array}{l}4.96 \\
5.24\end{array}$ & 4.39 & $.036^{*}$ & $\begin{array}{l}31.74 \\
31.33\end{array}$ & $\begin{array}{l}5.82 \\
5.78\end{array}$ & 1.17 & .279 & $\begin{array}{l}24.39 \\
23.96\end{array}$ & $\begin{array}{l}5.66 \\
5.84\end{array}$ & 1.32 & .250 & $\begin{array}{l}36.13 \\
35.47\end{array}$ & $\begin{array}{l}5.84 \\
5.98\end{array}$ & 2.85 & .092 & $\begin{array}{l}27.15 \\
26.35\end{array}$ & $\begin{array}{l}.81 \\
4.62\end{array}$ & 6.61 & $.010 *$ \\
\hline $\begin{array}{l}\text { Checking } \\
\text { What } \\
\text { Friends Do }\end{array}$ & $\begin{array}{l}\mathrm{Y} \\
\mathrm{N}\end{array}$ & $\begin{array}{l}310 \\
679\end{array}$ & $\begin{array}{l}30.90 \\
32.49\end{array}$ & $\begin{array}{l}5.42 \\
4.83\end{array}$ & 21.41 & $.000^{*}$ & $\begin{array}{l}30.13 \\
32.26\end{array}$ & $\begin{array}{l}5.75 \\
5.71\end{array}$ & 29.39 & $.000^{*}$ & $\begin{array}{l}25.66 \\
23.58\end{array}$ & $\begin{array}{l}5.39 \\
5.77\end{array}$ & 28.64 & $.000 *$ & $\begin{array}{l}35.92 \\
35.87\end{array}$ & $\begin{array}{l}5.76 \\
5.96\end{array}$ & 0.20 & .888 & $\begin{array}{l}27.64 \\
26.50\end{array}$ & $\begin{array}{l}4.67 \\
4.75\end{array}$ & 12.44 & $.000 *$ \\
\hline Recreation & $\begin{array}{l}\mathrm{Y} \\
\mathrm{N} \\
\end{array}$ & $\begin{array}{l}594 \\
395\end{array}$ & $\begin{array}{l}31.88 \\
32.16 \\
\end{array}$ & $\begin{array}{l}5.19 \\
4.88\end{array}$ & .696 & .404 & $\begin{array}{l}30.77 \\
32.82\end{array}$ & $\begin{array}{l}5.67 \\
5.79\end{array}$ & 30.20 & $.000^{*}$ & $\begin{array}{l}24.60 \\
23.68 \\
\end{array}$ & $\begin{array}{l}5.78 \\
5.62 \\
\end{array}$ & 6.15 & $.013 *$ & $\begin{array}{l}35.84 \\
35.95 \\
\end{array}$ & $\begin{array}{l}6.10 \\
5.59\end{array}$ & .085 & .771 & $\begin{array}{l}27.17 \\
26.40\end{array}$ & $\begin{array}{l}4.79 \\
4.67\end{array}$ & 2.24 & $.013 *$ \\
\hline
\end{tabular}


Yllmaz, A., \& Bilgin, M. (2017). The relationship between social network usage and some personality traits. Journal of Human Sciences, 14(3), 2219-2243. doi:10.14687/jhs.v14i3.4659

Given Table 3, it can be seen that the adolescents' preference regarding finding new friends statistically significantly vary between arithmetical mean scores of self-control $(\mathrm{F}=6.13, \mathrm{p}<.05)$ subscale. The preferences regarding chatting online statistically significantly vary between arithmetical mean scores from tendermindedness $(F=1.57, p<.05)$, self-control $(F=9.22, p<.05)$ and extroversion $(\mathrm{F}=21.14, \mathrm{p}<.05)$ subscales. The preferences regarding sharing photos statistically significantly vary between arithmetical mean scores from neuroticism $(\mathrm{F}=18.46, \mathrm{p}<.05)$ and extroversion $(\mathrm{F}=20.70, \mathrm{p}<.05)$ subscales. The preferences regarding commenting statistically significantly vary between arithmetical mean scores from $(\mathrm{F}=8.66, \mathrm{p}<.05)$ and extroversion $(\mathrm{F}=10.42, \mathrm{p}<.05)$ subscales. The preferences regarding accessing to information statistically significantly vary between arithmetical mean scores from self-control $(F=5.95, p<.05)$, openness for improvement $(\mathrm{F}=16.59, \mathrm{p}<.05)$ and extroversion $(\mathrm{F}=5.19, \mathrm{p}<.05)$ subscales. The preferences regarding sharing video statistically significantly vary between arithmetical mean scores from selfcontrol $(\mathrm{F}=5.71, \mathrm{p}<.05)$ and extroversion $(\mathrm{F}=4.55, \mathrm{p}<.05)$ subscales. The preferences regarding sharing news statistically significantly vary between arithmetical mean scores from openness for improvement $(\mathrm{F}=10.43, \mathrm{p}<.05)$ and extroversion $(\mathrm{F}=12.16, \mathrm{p}<.05)$ subscales. The preferences regarding playing games statistically significantly vary between arithmetical mean scores from selfcontrol $(\mathrm{F}=7.33, \mathrm{p}<.05)$ and neuroticism $(\mathrm{F}=17.31, \mathrm{p}<.05)$ subscales. The preferences regarding communicating with friends statistically significantly vary between arithmetical mean scores from tendermindedness $(\mathrm{F}=4.39, \mathrm{p}<.05)$ and extroversion $(\mathrm{F}=6.61, \mathrm{p}<.05)$ subscales. The preferences regarding checking what the friends do statistically significantly vary between arithmetical mean scores from tendermindedness $(\mathrm{F}=21.41, \mathrm{p}<.05)$, self-control $(\mathrm{F}=29.39, \mathrm{p}<.05)$, neuroticism $(\mathrm{F}=28.64, \mathrm{p}<.05)$ and extroversion $(\mathrm{F}=12.44, \mathrm{p}<.05)$ subscales. The preferences regarding the recreation statistically significantly vary between arithmetical mean scores from self-control $(\mathrm{F}=30.20, \mathrm{p}<.05)$, neuroticism $(\mathrm{F}=6.15, \mathrm{p}<.05)$ and extroversion $(\mathrm{F}=2.24, \mathrm{p}<.05)$ subscales.

Considering the source of differences seen between the adolescents' purposes of using social network by the scores from Five-Factor personality traits scale, it can be seen that mean score of those using social network for finding new friends from subscale of self-control $(X=30.62)$ was lower than that of those not using for that purpose $(X=31.80)$. Of those using the social network for chatting online, the mean score from subscale of tendermindedness $(X=32.00)$ was higher than that of those not using for that purpose $(X=31.99)$. Of those using the social network for chatting online, the mean score from subscale of self-control $(X=31.05)$ was lower than that of those not using for that purpose $(X=32.16)$. Of those using the social network for chatting online, the mean score from subscale of extroversion $(X=27.53)$ was higher than that of those not using for that purpose $(X=26.14)$.

The mean score of those using the social network for sharing photos from subscale of neuroticism $(X=25.20)$ was higher than that of those of not using for this purpose $(X=23.61)$. On the other hand, the mean score of those using the social network for sharing photos from subscale of extroversion $(X=27.70)$ was higher than that of those of not using for this purpose $(X=26.31)$. The mean score of those using the social network for commenting from subscale of self-control $(X=30.50)$ was determined to be lower than that of those of not using for this purpose $(X=31.86)$. The mean score of those using the social network for commenting from the subscale of extroversion $(X=27.83)$ was found to be higher than that of those of not using for this purpose $(X=26.61)$. The mean score of those using the social network for accessing to the information from subscale of self-control $(\mathrm{X}=31.93)$ was higher than that of those of not using for this purpose $(X=31.00)$. The mean score of those using the social network for accessing to the information from the openness for improvement $(X=36.18)$ subscale was lower than that of those of not using for this purpose $(X=36.47)$. The mean score of those using the social network for accessing to the information from of extroversion $(X=27.12)$ subscale was higher than that of those of not using for this purpose $(\mathrm{X}=26.41)$.

The mean score of those using the social network for sharing video from subscale of selfcontrol $(X=30.57)$ was calculated to be lower than that of those of not using for this purpose 
Yllmaz, A., \& Bilgin, M. (2017). The relationship between social network usage and some personality traits. Journal of Human Sciences, 14(3), 2219-2243. doi:10.14687/jhs.v14i3.4659

$(\mathrm{X}=31.78)$. The mean score of those using the social network for sharing video from subscale of extroversion $(X=27.60)$ was found to be higher than that of those of not using for this purpose $(X=26.72)$. The mean score of those using the social network for sharing news from subscale of openness for improvement $(\mathrm{X}=37.31)$ was higher than that of those of not using for this purpose $(\mathrm{X}=35.63)$. The mean score of those using the social network for sharing news from subscale of extroversion $(\mathrm{X}=26.63)$ was calculated to be lower than that of those of not using for this purpose $(X=28.09)$. The mean score of those using the social network for playing game from subscale of self-control $(\mathrm{X}=30.89)$ was determined to be lower than that of those of not using for this purpose $(\mathrm{X}=31.94)$. The mean score of those using the social network for playing game from subscale of neuroticism $(\mathrm{X}=23.18)$ was found to be lower than that of those of not using for this purpose $(\mathrm{X}=24.77)$.

The mean score of those using the social network for communicating with friends from subscale of tendermindedness $(\mathrm{X}=32.25)$ was higher than that of those of not using for this purpose $(X=31.55)$. The mean score of those using the social network for communicating with friends from subscale of extroversion $(X=27.15)$ was found to be higher than that of those of not using for this purpose $(X=26.35)$. The mean score of those using the social network for checking what the friends do from subscale of tendermindedness $(X=30.90)$ was found to be lower than that of those of not using for this purpose $(\mathrm{X}=32.49)$. The mean score of those using the social network for checking what the friends do from the neuroticism $(X=25.66)$ subscale was determined to be higher than that of those of not using for this purpose $(X=23.58)$. The mean score of those using the social network for checking what the friends do from subscale of extroversion $(X=27.64)$ was higher than that of those of not using for this purpose $(X=26.50)$. The mean score of those using the social network for recreation from the subscale of self-control $(X=30.77)$ was lower than that of those of not using for this purpose $(\mathrm{X}=32.82)$. The mean score of those using the social network for recreation from neuroticism $(\mathrm{X}=24.60)$ subscale was higher than that of those of not using for this purpose $(\mathrm{X}=23.68)$. The mean score of those using the social network for recreation from the subscale of extroversion $(\mathrm{X}=27.17)$ was higher than that of those of not using for this purpose $(\mathrm{X}=26.40)$.

\section{Is There Statistically Significant Difference between Mean Scores from Five-Factor Personal Traits by the Social Media Accounts used?}

The results of MANOVA, which was applied to Five-Factor Inventory of adolescents, indicate differences in Facebook (Wilks Lambda=.990, $\mathrm{F}(1,987)=1.90, \mathrm{p}<0.5$ ), Twitter (Wilks Lambda=.966, F(1, 987)=6.94, p<0.5), Google + (Wilks Lambda=.979, F(1, 987)=4.31, p<0.5), YouTube (Wilks Lambda=.966, F(1, 987)=6.87, $\mathrm{p}<0.5$ ), Instagram (Wilks Lambda=.931, F(1, 987 ) $=14.56, \mathrm{p}<0.5$ ), Foursquare (Wilks Lambda $=.958, \mathrm{~F}(1,987)=8.52, \mathrm{p}<0.5$ ), Vine (Wilks Lambda $=.946, F(1,987)=11.29, \mathrm{p}<0.5)$, BlogSpot (Wilks Lambda=.992, $\mathrm{F}(1,987)=1.63, \mathrm{p}<0.5)$, Tumblr (Wilks Lambda $=.966, \mathrm{~F}(1,987)=6.88, \mathrm{p}<0.5$ ), Pinterest (Wilks Lambda $=.980, \mathrm{~F}(1$, 987) $=3.97, \mathrm{p}<0.5$ ), Skype (Wilks Lambda=.957, F(1, 987)=8.77, p<0.5), and WhatsApp (Wilks Lambda $=.964, \mathrm{~F}(1,987)=7.31, \mathrm{p}<0.5)$ accounts by the Five-Factor personality traits scale. This finding indicates that the scores to be obtained from the linear elements consisting of adolescent's Five-Factor personal traits vary depending on the social network accounts. The results of one-way MANOVA applied to the mean and standard deviation values of adolescents' Five-Factor personality traits according to the social network accounts are presented in Table 4. 
2228

Yllmaz, A., \& Bilgin, M. (2017). The relationship between social network usage and some personality traits. Journal of Human Sciences, 14(3), 2219-2243. doi:10.14687/ihs.v14i3.4659

Table 4

Mean, Standard Deviation and MANOVA Results of Adolescents' Social Media Accounts by Their Five-Factor personality Traits

\begin{tabular}{|c|c|c|c|c|c|c|c|c|c|c|c|c|c|c|c|c|c|c|c|c|c|c|}
\hline \multirow{2}{*}{\multicolumn{2}{|c|}{$\begin{array}{l}\text { Personality } \\
\text { Traits } \\
\text { Social Networks }\end{array}$}} & \multirow{2}{*}{$\begin{array}{l}\text { Numb } \\
\text { er } \\
\mathrm{n}\end{array}$} & \multicolumn{4}{|c|}{ Tendermindedness } & \multicolumn{4}{|c|}{ Self-control } & \multicolumn{4}{|c|}{ Neuroticism } & \multicolumn{4}{|c|}{ Openness for improvement } & \multicolumn{4}{|c|}{ Extroversion } \\
\hline & & & $\mathrm{X}$ & $\mathrm{S}$ & $\mathrm{F}$ & $\mathrm{P}$ & $\mathrm{X}$ & $\mathrm{S}$ & $\mathrm{F}$ & $\mathrm{P}$ & $\mathrm{X}$ & $\mathrm{S}$ & $\mathrm{F}$ & $\mathrm{P}$ & $\mathrm{X}$ & $\mathrm{S}$ & $\mathrm{F}$ & $\mathrm{P}$ & $\mathrm{X}$ & $\mathrm{S}$ & $\mathrm{F}$ & $\mathrm{P}$ \\
\hline \multirow[t]{2}{*}{ Facebook } & $\mathrm{Y}$ & 757 & 32.10 & 4.86 & 1.59 & .207 & 31.56 & 5.72 & .076 & .783 & 24.02 & 5.74 & 4.41 & $.036^{*}$ & 36.05 & 5.78 & 2.50 & .114 & 26.88 & 4.74 & .057 & .812 \\
\hline & $\mathrm{N}$ & 232 & 31.62 & 5.69 & & & 31.68 & 6.07 & & & 24.93 & 5.66 & & & 35.35 & 6.25 & & & 26.79 & 4.82 & & \\
\hline \multirow[t]{2}{*}{ Twitter } & Y & 342 & 31.49 & 5.18 & 5.09 & $.024 *$ & 30.79 & 5.97 & 10.03 & $.002 *$ & 24.62 & 5.89 & 2.33 & .127 & 36.77 & 5.99 & 11.88 & $.001 *$ & 27.47 & 4.73 & 8.76 & $.003 *$ \\
\hline & $\mathrm{N}$ & 647 & 32.26 & 4.99 & & & 32.01 & 5.67 & & & 24.03 & 5.64 & & & 35.42 & 5.80 & & & 26.53 & 4.74 & & \\
\hline \multirow[t]{2}{*}{ Google + } & $\mathrm{Y}$ & 574 & 32.23 & 5.14 & 3.06 & .080 & 31.38 & 5.86 & 1.76 & .184 & 24.06 & 5.82 & 1.22 & .268 & 36.40 & 5.77 & 10.70 & $.001 *$ & 27.01 & 4.72 & 1.38 & .240 \\
\hline & $\mathrm{N}$ & 415 & 31.66 & 4.96 & & & 31.88 & 5.72 & & & 24.47 & 5.61 & & & 35.17 & 6.01 & & & 26.65 & 4.80 & & \\
\hline \multirow[t]{2}{*}{ YouTube } & $\mathrm{Y}$ & 573 & 32.03 & 5.23 & 0.69 & .793 & 31.16 & 5.95 & 7.31 & $.007 *$ & 24.10 & 5.88 & .754 & .386 & 36.47 & 5.74 & 13.54 & $.000 *$ & 27.21 & 4.83 & 7.50 & $.006^{*}$ \\
\hline & $\mathrm{N}$ & 416 & 31.94 & 4.85 & & & 32.17 & 5.55 & & & 24.42 & 5.52 & & & 35.08 & 6.02 & & & 26.37 & 4.61 & & \\
\hline \multirow[t]{2}{*}{ İnstagram } & Y & 585 & 31.88 & 5.07 & 691 & .406 & 31.17 & 5.83 & 7.44 & $.006 *$ & 24.75 & 5.67 & 11.79 & $.001 *$ & 36.56 & 5.79 & 19.22 & $.000 *$ & 27.65 & 4.67 & 40.90 & $.000 *$ \\
\hline & $\mathrm{N}$ & 404 & 32.15 & 5.07 & & & 32.19 & 5.72 & & & 23.49 & 5.75 & & & 34.90 & 5.92 & & & 25.72 & 4.65 & & \\
\hline \multirow[t]{2}{*}{ Foursquare } & $\mathrm{Y}$ & 90 & 30.73 & 5.42 & 6.17 & $.013 *$ & 28.75 & 5.60 & 24.19 & $.000 *$ & 25.53 & 5.62 & 5.05 & $.025 *$ & 35.98 & 6.29 & .028 & .867 & 28.51 & 4.72 & 12.00 & $.001 *$ \\
\hline & $\mathrm{N}$ & 899 & 32.12 & 5.02 & & & 31.87 & 5.75 & & & 24.11 & 5.73 & & & 35.87 & 5.86 & & & 26.69 & 4.82 & & \\
\hline \multirow[t]{2}{*}{ Vine } & $\mathrm{Y}$ & 212 & 31.26 & 5.00 & 5.58 & $.018^{*}$ & 30.16 & 6.11 & 16.46 & $.000 *$ & 24.33 & 5.76 & .074 & .785 & 37.32 & 6.07 & 16.20 & $.000 *$ & 28.03 & 4.57 & 16.70 & $.000 *$ \\
\hline & $\mathrm{N}$ & 777 & 32.19 & 5.07 & & & 31.98 & 5.66 & & & 24.21 & 5.73 & & & 35.49 & 5.79 & & & 26.54 & 4.76 & & \\
\hline \multirow[t]{2}{*}{ BlogSpot } & $\mathrm{Y}$ & 45 & 30.51 & 6.17 & 4.05 & $.044 *$ & 29.62 & 6.57 & 5.45 & $.020 *$ & 25.15 & 6.56 & 1.20 & .273 & 36.22 & 7.02 & .149 & .699 & 26.97 & 3.91 & .028 & .868 \\
\hline & $\mathrm{N}$ & 944 & 32.06 & 5.00 & & & 31.68 & 5.75 & & & 24.19 & 5.69 & & & 35.87 & 5.84 & & & 26.85 & 4.79 & & \\
\hline \multirow[t]{2}{*}{ Tumblr } & $\mathrm{Y}$ & 160 & 31.14 & 5.35 & 5.42 & $.020 *$ & 30.58 & 6.02 & 5.75 & $.017 *$ & 24.10 & 5.67 & 2.88 & .090 & 37.60 & 5.74 & 16.26 & $.000 *$ & 27.84 & 5.14 & 8.16 & $.004 *$ \\
\hline & $\mathrm{N}$ & 829 & 32.16 & 5.00 & & & 31.78 & 5.74 & & & 24.94 & 6.01 & & & 35.55 & 5.87 & & & 26.67 & 4.66 & & \\
\hline \multirow[t]{2}{*}{ Pinterest } & $\mathrm{Y}$ & 35 & 31.31 & 5.97 & .656 & .418 & 27.80 & 6.72 & 15.70 & $.000 *$ & 25.68 & 5.83 & 2.30 & .129 & 36.88 & 6.55 & 1.03 & $.000 *$ & 27.37 & 3.63 & .414 & .520 \\
\hline & $\mathrm{N}$ & 954 & 32.02 & 5.04 & & & 31.73 & 5.72 & & & 24.18 & 5.72 & & & 35.85 & 5.87 & & & 26.84 & 4.79 & & \\
\hline \multirow[t]{2}{*}{ Skype } & $\mathrm{Y}$ & 313 & 32.03 & 5.04 & .030 & .862 & 30.74 & 5.92 & 9.94 & $.002 *$ & 23.93 & 5.68 & 1.31 & .253 & 36.73 & 6.12 & 9.53 & $.002 *$ & 27.76 & 4.93 & 16.66 & $.000 *$ \\
\hline & $\mathrm{N}$ & 676 & 31.97 & 5.09 & & & 31.98 & 5.71 & & & 24.38 & 5.75 & & & 35.49 & 5.75 & & & 26.44 & 4.62 & & \\
\hline \multirow[t]{2}{*}{ WhatsApp } & $\mathrm{Y}$ & 722 & 31.95 & 5.20 & .154 & .695 & 31.27 & 5.85 & 7.85 & $.005 *$ & 24.45 & 5.80 & 3.80 & .051 & 36.26 & 5.87 & 10.96 & $.001 *$ & 27.22 & 4.74 & 15.80 & $.000 *$ \\
\hline & $\mathrm{N}$ & 267 & 32.10 & 4.72 & & & 32.44 & 5.61 & & & 23.65 & 5.51 & & & 34.87 & 5.86 & & & 25.88 & 4.66 & & \\
\hline
\end{tabular}


Bilgin, M., Yilmaz, A. (2017). The relationship between social network usage and some personality traits. Journal of Human Sciences, 14(3), 2208-2232. doi:10.14687/jhs.v14i3.4659

Given Table 4, the preferences of adolescents regarding the use of Facebook varies significantly between arithmetical mean scores of neuroticism $(\mathrm{F}=4.41, \mathrm{p}<.05)$ subscale. The preferences regarding the use of Twitter significantly varied between arithmetical mean scores of tendermindedness $(\mathrm{F}=5.09, \mathrm{p}<.05)$, self-control $(\mathrm{F}=10.03, \mathrm{p}<.05)$, openness for improvement $(\mathrm{F}=11.88, \mathrm{p}<.05)$ and extroversion $(\mathrm{F}=8.76, \mathrm{p}<.05)$ subscales. The preferences regarding the use of Google+ significantly varied between arithmetical mean scores of openness for improvement $(\mathrm{F}=10.70, \mathrm{p}<.05)$ subscale, while those about the use of YouTube significantly varied between arithmetical mean scores of self-control $(\mathrm{F}=7.31, \mathrm{p}<.05)$, openness for improvement $(\mathrm{F}=13.54$, $\mathrm{p}<.05)$ and extroversion $(\mathrm{F}=7.50, \mathrm{p}<.05)$ subscales. The preferences of users about the use of Instagram significantly varied between arithmetical mean scores of self-control $(\mathrm{F}=7.44, \mathrm{p}<.05)$, neuroticism $(\mathrm{F}=11.79, \mathrm{p}<.05)$, openness for improvement $(\mathrm{F}=19.22, \mathrm{p}<.05)$ and extroversion $(\mathrm{F}=40.90, \mathrm{p}<.05)$ subscales. While the preferences of users regarding the use of Foursquare significantly varied between arithmetical mean scores of tendermindedness ( $\mathrm{F}=6.17, \mathrm{p}<.05)$, selfcontrol $(\mathrm{F}=24.19, \mathrm{p}<.05)$, neuroticism $(\mathrm{F}=5.05, \mathrm{p}<.05)$ and extroversion $(\mathrm{F}=12.00, \mathrm{p}<.05)$ subscales, those about the use of Vine significantly varied between arithmetical mean scores of tendermindedness $(\mathrm{F}=5.58, \mathrm{p}<.05)$, self-control $(\mathrm{F}=16.46, \mathrm{p}<.05)$, openness for improvement $(\mathrm{F}=16.20, \mathrm{p}<.05)$ and extroversion $(\mathrm{F}=16.70, \mathrm{p}<.05)$ subscales. The preferences about the use of BlogSpot significantly varied between arithmetical mean scores of tendermindedness $(\mathrm{F}=4.05$, $\mathrm{p}<.05)$ and self-control $(\mathrm{F}=5.45, \mathrm{p}<.05)$ subscales, while those about the use of Tumblr significantly varied between arithmetical mean scores of tendermindedness $(\mathrm{F}=5.42, \mathrm{p}<.05)$, selfcontrol $(\mathrm{F}=5.75, \mathrm{p}<.05)$, openness for improvement $(\mathrm{F}=16.26, \mathrm{p}<.05)$ and extroversion $(\mathrm{F}=8.16$, $\mathrm{p}<.05)$ subscales. While the preferences of users regarding the use of Pinterest significantly varied between arithmetical mean scores of self-control $(\mathrm{F}=15.70, \mathrm{p}<.05)$ and openness for improvement $(\mathrm{F}=1.03, \mathrm{p}<.05)$ subscales, those regarding the use of Skype significantly varied between arithmetical mean scores of self-control $(\mathrm{F}=9.94, \mathrm{p}<.05)$, openness for improvement $(\mathrm{F}=9.53$, $\mathrm{p}<.05)$ and extroversion $(\mathrm{F}=16.66, \mathrm{p}<.05)$ subscales. And, finally, the preferences of users about the use of WhatsApp significantly also varied between arithmetical mean scores of self-control $(\mathrm{F}=7.85, \mathrm{p}<.05)$, openness for improvement $(\mathrm{F}=10.96, \mathrm{p}<.05)$ and extroversion $(\mathrm{F}=15.80, \mathrm{p}<.05)$ subscales.

Considering the source of difference between the social network accounts of adolescents depending on their scores from Five-Factor personality trait scale, the mean score of those using Facebook from the subscale of neuroticism subscale $(X=24.02)$ was lower than that of those not using $(X=24.93)$. The mean score of those using Twitter from subscale of tendermindedness $(X=31.49)$ was lower than that of those not using $(X=32.26)$. The mean score of those using Twitter from subscale of self-control $(X=30.79)$ was lower than that of those not using $(X=32.01)$, while the mean score of those using Twitter from the subscale of openness for improvement $(X=36.77)$ was higher than that of those not using $(X=35.42)$. The mean score of those using Twitter from subscale of extroversion $(X=27.47)$ was higher than that of those not using $(X=26.53)$, while the mean score of those using Google+ from the subscale of openness for improvement $(X=36.40)$ was higher than that of those not using $(X=35.17)$. The mean score of those using YouTube from subscale of self-control $(\mathrm{X}=31.16)$ was lower than that of those not using $(\mathrm{X}=32.17)$. The mean score of those using YouTube from subscale of openness for improvement $(X=36.47)$ was higher than that of those not using $(X=35.08)$, while the mean score of those using YouTube from subscale of extroversion $(X=27.21)$ was higher than that of those not using $(\mathrm{X}=26.37)$.

The mean score of those using Instagram from subscale of self-control ( $X=31.17)$ was lower than that of those not using $(X=32.19)$. The mean score of those using Instagram from subscale of neuroticism $(X=24.75)$ was higher than that of those not using $(X=23.49)$. The mean score of those using Instagram from subscale of openness for improvement $(X=36.56)$ was higher than that of those not using $(X=34.90)$. The mean score of those using Instagram from subscale of 
Bilgin, M., Yilmaz, A. (2017). The relationship between social network usage and some personality traits. Journal of Human Sciences, 14(3), 2219-2243. doi:10.14687/jhs.v14i3.4659

extroversion $(X=27.65)$ was higher than that of those not using $(X=25.72)$. The mean score of those using Foursquare from subscale of tendermindedness $(\mathrm{X}=30.73)$ was lower than that of those not using $(\mathrm{X}=32.12)$. The mean score of those using Foursquare from subscale of self-control $(X=28.75)$ was lower than that of those not using $(X=31.87)$. The mean score of those using Foursquare from subscale of neuroticism $(X=25.53)$ was higher than that of those not using $(X=24.11)$. The mean score of those using Foursquare from subscale of extroversion $(X=28.51)$ was higher than that of those not using $(X=26.69)$. The mean score of those using Vine from subscale of tendermindedness $(X=31.26)$ was lower than that of those not using $(X=32.19)$. The mean score of those using Vine The mean score of those using from subscale of self-control $(X=30.16)$ was lower than that of those not using $(X=31.98)$. The mean score of those using Vine from subscale of openness for improvement $(X=37.32)$ was higher than that of those not using $(X=35.49)$. The mean score of those using Vine from subscale of extroversion $(X=28.03)$ was higher than that of those not using $(X=26.54)$.

The mean score of those using BlogSpot from subscale of tendermindedness $(X=30.51)$ was lower than that of those not using $(X=32.06)$. The mean score of those using BlogSpot from subscale of self-control $(X=29.62)$ was lower than that of those not using $(X=31.68)$. The mean score of those using Tumblr from subscale of tendermindedness $(X=31.14)$ was lower than that of those not using $(\mathrm{X}=32.16)$. The mean score of those using Tumblr from subscale of self-control $(X=30.58)$ was lower than that of those not using $(X=31.78)$. The mean score of those using Tumblr from subscale of openness for improvement $(X=37.60)$ was higher than that of those not using $(X=35.55)$. The mean score of those using Tumblr from subscale of extroversion $(X=27.84)$ was higher than that of those not using $(X=26.67)$. The mean score of those using Pinterest from subscale of self-control $(X=27.80)$ was lower than that of those not using $(X=31.73)$. The mean score of those using Pinterest from subscale of openness for improvement $(X=36.88)$ was higher than that of those not using $(X=35.85)$. The mean score of those using Skype from subscale of selfcontrol $(X=30.74)$ was lower than that of those not using $(X=31.98)$. The mean score of those using Skype from subscale of openness for improvement $(X=36.73)$ was higher than that of those not using $(X=35.49)$. The mean score of those using Skype from subscale of extroversion $(X=27.76)$ was higher than that of those not using $(X=26.44)$. The mean score of those using WhatsApp from subscale of self-control $(X=31.27)$ was lower than that of those not using $(\mathrm{X}=32.44)$. The mean score of those using WhatsApp from subscale of openness for improvement $(X=36.26)$ was higher than that of those not using $(X=34.87)$. The mean score of those using WhatsApp from subscale of extroversion $(X=27.22)$ was higher than that of those not using $(\mathrm{X}=25.88)$.

\section{DISCUSSION AND INTERPRETATIONS}

In this section, the discussion and interpretations on the findings obtained from this study, where the relation between adolescents' use of social networks and their Five-Factor personality traits is examined, are presented in parallel with the sub-objectives.

\section{Discussion and Interpretation on if there is Significant Difference between Mean Durations of Using Social Networks by the Five-Factor personality Traits}

Considering if there is any statistically significant difference between the mean scores in Five-Factor personality trait scales by the durations of adolescents' use of social network, significant differences were found between the mean scores in Five-Factor personality trait scale by the durations of use of social network.

While statistically significant difference was found between hours of using social networks and subscales of self-control, neuroticism and extroversion, no statistically significant difference was determined in sub-dimensions of tendermindedness and openness for improvement. 
Bilgin, M., Yilmaz, A. (2017). The relationship between social network usage and some personality traits. Journal of Human Sciences, 14(3), 2219-2243. doi:10.14687/ihs.v14i3.4659

Statistically significant difference was found between durations of using the social networks and neuroticism sub-dimension of Five-Factor personality traits. There is a positive relation between the personality trait of "neuroticism" and the duration of using social network. It was observed that the neuroticism trait of adolescents spending more time in using social networks were higher. When compared to other adolescents, those spending more time in social networks can be described as anxious, depressed, distressful, and distrustful. Subrahmanyam et al. (2008) have reported that $54 \%$ of the users spend more than 1 hour in social networks, while Kim and Davis (2009) reported that $68.9 \%$ of the users spend more than 1 hour a day in social networks. The Council of Internet in Ministry of Transportation (2011) has emphasized that $66 \%$ of the users spend time for at least once a day and this duration is 72 minutes. Correa et al. (2010) have reported positive correlation of use of social media with extroversion and openness for improvement, and negative correlation with neuroticism. Wehrli (2008) has asserted that extroversion play significant role in establishing network-based connections.

Statistically significant difference was found between durations of using the social networks and extroversion sub-dimensions of Five-Factor personality traits. There is a positive relation between the personality trait of extroversion and hours spent in social networks. It was observed that the extroversion trait of adolescents spending more time in using social networks were higher. When compared to other adolescents, those spending more time in social networks can be described as more social, vivid, enthusiastic, and sociable. In this study, it was determined that the adolescents having higher level of extroversion spend more time in social networks. This finding is in corroboration with those of Wehrli (2008) and Correa et al. (2010). The extroversive persons are social, talkative, assertive, and active. Because of these traits of extroversive persons, they might be thought to spend more time on social networks. These individuals tend to spend more time outside their social environments when compared to other individuals. Social networks might be providing them with an appropriate medium for using this trait of them.

Statistically significant difference was found between durations of using the social networks and self-control sub-dimension of Five-Factor personality traits. There is a negative relation between self-control trait and hours spent on social networks. As the level of self-control increases, then the hours spent in using social networks decrease. No study finding in literature could be found in relation with this finding. The persons having high level of self-control are careful/attentive, responsible, and consistent. It may be asserted that they are more selective because of this personality trait of them. For this reason, it may cause a decrease in hours spent on social networks.

Statistically significant difference was found between durations of using the social networks and tendermindedness sub-dimension of Five-Factor personality traits. Given the studies in literature, no relationship was found between tendermindedness and hours spent on social media. (Correa et al., 2010; Hughes et al., 2011; Ross et al., 2009).

Statistically significant difference was found between durations of using the social networks and openness for improvement sub-dimension of Five-Factor personality traits. But, Dal and Dal (2014) have reported that the mean durations of using social networking sites increased as the mean scores of openness for improvement increased.

\section{Discussion and Interpretation on if there is Significant Difference between Mean Scores from Five-Factor personality Traits Scale by the Purposes of Using Social Networks}

Considering if there is any statistically significant difference between the mean scores in Five-Factor personality trait scale by the purposes of adolescents' for using the social networks, significant differences were found between the mean scores in Five-Factor personality trait scale by the purposes for using the social networks.

In social media use of adolescents, significant differences were found between the purpose of "baving new friends" and self-control trait. Negative relationship was found between the self- 
Bilgin, M., Yilmaz, A. (2017). The relationship between social network usage and some personality traits. Journal of Human Sciences, 14(3), 2219-2243. doi:10.14687/jhs.v14i3.4659

control personality trait of adolescents using social media for finding new friends and their selfcontrol trait. In literature, Şener (2009) has emphasized that Facebook is being used for developing the existing friendships, rather than having new ones. This study is in corroboration with that of Şener. Bonetti, Campbell and Gilmore (2010) have concluded that the adolescents experiencing loneliness preferred virtual communication in Internet over face-to-face communication for meeting new peoples.

According to the findings of present study, reactive persons, who are impatient and careless and behaving without thinking, are more enthusiastic about having new friends, when compared to individuals behaving consideringly.

The statistically significant difference was found between the purpose of "online chatting” and the tendermindedness, self-control and extroversion personality traits. Positive relationship was found between tendermindedness and self-control personality traits of adolescents using social media for chatting online. In study of Deniz (2012), it was reported that chatting is a very common objective in social media. The individuals being enthusiastic about chatting online are likely to be prudent, self-controlled, and objective-oriented. The persons having high level of self-control do not consider the online chat as a threat. On the other hand, the tenderminded persons are more likely to be trustful, helpful, and honest. The tenderminded persons can maintain the online chat, because they are likely to exhibit higher level of adaptation/obedience. Negative relationship was found with personality trait of extroversion. Extroversive persons are self-confident, dominant, and active individuals. Because of these traits of them, they can be thought to prefer face-to-face conversation over online chatting.

The statistically significant difference was found between the purpose of "sharing photos" and the personality traits of neuroticism and extroversion. Among the adolescents using the social media for sharing photos, negative relationship was found between personality traits of neuroticism and extroversion. The depressive, distressed, and emotionally reactive (among the sub-dimensions of neuroticism) persons were observed to share less photos. In literature, it has been reported that neurotic individuals are more prone to receive/send comment during using the "wall" feature of Facebook, while those having low level of neuroticism send more photos (Ross, Orr, Sisic, Arseneault, Simmering and Orr 2009). In another study, it has been concluded that, on the contrary with previous findings, the neurotic individuals are prone to share more photos (AmichaiHamburger and Vinitzky, 2010). The reason for this action might be that these persons may believe that sharing fewer photos might bring less likes or their posts would be liked by less people when they post fewer photos. Wang, Jackson, Zhang and Su (2012) have showed that extroversion is in positive relation with sharing one's own photos on social media. Wang et al., in their study, have emphasized that there was a negative relationship with extroversion among the adolescents using the social network sites for sharing photos. Extroversive individuals are enthusiastic, social, happy, and talkative persons. Extroversive adolescents may not prefer sharing photos since they may not consider it as a social activity. Gosling et al. (2011) have determined a positive relationship between the number of photos shared and added and the scores of openness for improvement. In this study, no relationship was determined between sharing photos in social media and openness for improvement among the adolescent population.

The statistically significant difference was found between the purpose of "commenting" and the self-control and extroversion. While, among the adolescents using social media for commenting, positive relationship was found with self-control, negative relationship was found with extroversion. Buckner, Castille and Sheets (2012) have stated that commenting on social networking sites is positively related with self-control. The findings of present study are in corroboration with these results. Self-control requires inner discipline; self-controlled persons know their social limits. Thus, since they know how to speak to whom, they may not hesitate from commenting in social media. Wang et al. (2012) have concluded that extroversion is positively relationship with commenting in social networking sites. On contrary with the study of Wang et al., 
Bilgin, M., Yilmaz, A. (2017). The relationship between social network usage and some personality traits. Journal of Human Sciences, 14(3), 2219-2243. doi:10.14687/ihs.v14i3.4659

it was found in present study that, among the adolescents using social media for commenting, there is a negative relationship with extroversion. Extroversive adolescents may not prefer commenting since they don't consider it as a social activity.

The statistically significant difference was found between the purpose of "getting the information" and the self-control, openness for improvement and extroversion traits. Among the adolescents using the social media for accessing the information, there is negative relationship with self-control and extroversion traits and positive relationship with openness for improvement. Karaduman and Kurt (2010) have revealed that one of the purposes of using social media is to achieve the source of information. As a reason for negative relation with self-control trait of adolescents using the social media for getting the information, the fact that they are less prudent, rigorous and self-controlling persons may play significant role. Openness for improvement of the adolescents using the social media for getting the information was found to be in positive relationship. The developmentally-open persons are those with wide interests, being open to new ideas and being eager to accept other opinions. The persons, who are open to development, are open to new ideas, and thus they can use the social media for accessing to the information. Negative relationship was found with extroversion trait of adolescents using the social media for accessing to the knowledge. Extroversive persons are social and active individuals and, thus, they may prefer learning by sharing or learning from outer world.

The statistically significant difference was found between the purpose of "sharing video" and self-control and extroversion personality traits. Among the adolescents using the social media for sharing videos, positive relationship was found with self-control trait, while negative relationship was found with extroversion trait. Bat and Vural (2010) have concluded that the follow is at high level in social networking sites but sharing video is not as valuable as being followed. As a reason for that, they have expressed that majority of the users of such sites may be passive followers, that they may avoid from sharing videos that do not belong to them, or that they use those sites for personal satisfaction. Self-control trait of the adolescents using the social media for sharing videos was found to be in positive relationship. Self-controlled adolescents may use the social media as a platform for expressing their interests and skills by sharing videos. On the other hand, the extroversion trait of adolescents using the social media for sharing video was found to be in negative relationship. Extroversive adolescents may prefer being involved in others' videos or being the one shooting the video over sharing the videos.

The statistically significant difference was found between the purpose of "sharing news" and the openness for improvement and extroversion traits. Among the adolescents using the social media for sharing the news, negative relationship was found with openness for improvement, while positive relationship was determined with extroversion. Since the open-to-development adolescents are untraditional, original, unique, and open to new ideas and have high level of imaginary power, they may prefer sharing their own articles or news over sharing those of others. There is positive relationship with extroversion trait of adolescents using the social media for sharing the news. When compared to others, the extroversive adolescents might want to share news for first time since they have the characteristics of leadership, enthusiasm, and dominance.

The statistically significant difference was found between the purpose of "playing games" and the self-control and neuroticism traits. There is positive relationship with self-control and neuroticism traits of adolescents using the social media for playing games. The games improve the students' thinking skills, patience, tenacity, memory, and imaginary power (Mumtaz, 2001). Because of their ability to commit a task and being patient despite of being bored, the self-controlled individuals may spend hours in playing games. The persons having neuroticism trait are depressive, anxious, and depressed. The adolescents having these characteristics but playing games may be more addicted than other adolescents. This may result in being more anxious and depressive as the addiction develops. Wang et al. (2012) have determined that extroversion is negatively related with 
playing games in social networking sires. In this study, no relationship was found between playing game and extroversion trait.

The statistically significant difference was found between the purpose of "communicating with friends" and tendermindedness and extroversion traits. There is negative relationship with tendermindedness and extroversion traits of adolescents using the social media for communicating with friends. Most of the adolescents use the Internet for communicating with their friends (Gross, 2004). Young individuals use Internet also for communicating with strangers (Subrahmanyam and Greenfield, 2008; Valkenburg and Peter, 2007). Establishing with strangers may allow the adolescent to experience the sense of belonging. The alone, depressive, and anxious individuals were found to feel themselves less bounded in Internet, which they mainly use for emotional support, meeting with new people, and communicating with others. Moreover, these individuals generally prefer online communication and find the Internet communication to be sincerer and more supportive (Valkenburg and Peter, 2007). In this study, the findings differing from those of others were obtained. Since the tenderminded individuals have well-natured characteristics, they can establish connection of their friends and strangers. Since they feel in secure, they do not approach anybody in mistrustful manner. Thus, it can be thought that they do not hesitate from establishing communication. Besides that, there is a negative relationship with extroversion trait of adolescents using social media for communicating with friends. Extroversive adolescents are social individuals. They can establish connection whenever possible.

The statistically significant difference was found between the purpose of "checking what friends $d o$ " and the traits of tendermindedness, self-control, neuroticism and extroversion. Among the adolescents using the social media for checking what the friends do, there is positive relationship with tendermindedness and self-control traits, while negative relationships were found with neuroticism and extroversion traits. The tenderminded individuals may check their friends because they wonder what his/her friends are doing, since they are soft-hearted and well-natured persons. Self-controlled individuals behave responsibly; they may check for protecting their friends. Neurotic adolescents may feel more stressed and anxious when they follow other adolescents and see that they are happy and social. Extroversive adolescents seek for more individual interaction in more frequent manner, thus they may not need to check.

The statistically significant difference was found between the purpose of "recreation" and the self-control, neuroticism and extroversion traits. Among the adolescents using the social media for recreational purposes, there is positive relationship with self-control, while negative relationship was found with neuroticism and extroversion. Ök (2013) have determined that one of factors playing significant role in use of social media is to spend time. Bat and Vural (2010) have revealed that the students use social media most frequently for spending time. Şener (2009) has reported that one of two functions ensuring highest level of use of Facebook is the spare time activities. Selfcontrolled persons are responsible individuals, and they can use social media efficiently. Since neurotic adolescents using social media as a spared time activity spend their free time on social media, their anxiousness level may rise when they recognized the elapsed-time.

\section{Discussion and Interpretation on if there is Significant Difference between Mean Scores from Five-Factor personality Traits Scale by the Social Media Accounts being used}

Considering if there is any statistically significant difference between the mean scores in Five-Factor personality trait scale by the social media accounts being used, significant differences were found between the mean scores in Five-Factor personality trait scale by the social media accounts.

Significant difference and positive relation were found between neuroticism and Facebook, among the social media accounts used by adolescents.

The relationship of neurotic personality with the use of Facebook has been examined by many researchers. The first studies examining the relationship of neuroticism with the use of social 
Bilgin, M., Yilmaz, A. (2017). The relationship between social network usage and some personality traits. Journal of Human Sciences, 14(3), 2219-2243. doi:10.14687/ihs.v14i3.4659

networking sites revealed that the neurotic individuals use social networks relatively less (AmichaiHamburger, Wainapel and Fox, 2002; Amiel and Sargent, 2004). But, the studies in recent years showed that neurotics (Wehrli, 2008) and the persons having the characteristics of anxiousness and depressiveness, among the indicators of neuroticism, (Correa et al., 2010) spend more time in social network sites, especially in Facebook (Amichai-Hamburger and Vinitzky, 2010; Ross et al., 2009). This corroborates with the results of present study. When compared to other adolescents, the neurotic adolescents can be said to remove their sense of loneliness and decrease their level of anxiousness by using Facebook.

No relationship was found between the use of Facebook and the extroversion trait. One of the personality traits, relations of using Facebook with which have been examined at most, is the extroversion. Given the studies in literature, it can be seen that having the personality trait of extroversion was found to be positively related with the use of social networking sites (Correa et al., 2010; Wehrli, 2008). The extroversive individuals were found to spend more time in social networking sites (Wilson, Fornasier and White, 2010), to be a member of higher number of groups in Facebook and to have more friends (Ong, Ang, Ho, Lim, Goh, and Lee 2011). Even if Facebook is not considered an alternative to face-to-face conversation for extroversive persons (Amiel and Sargent, 2004), it can be seen that these individuals communicate with more people, announce higher number of events, and share more photos (Correa et al. 2010). Furthermore, it was also found that the extroversive individuals share more information (Wilson et al., 2010) and status updates (Amichai-Hamburger and Vinitzky, 2010) about themselves.

No relationship was found between adolescents' use of Facebook and self-control trait. It can be seen that personality trait of self-control has been widely examined in studies carried out on Facebook. In studies, where the relationship of self-control with the use of Internet and social networking sites was examined, it was found that those individuals used Internet and social media relatively less (Butt and Phillips, 2008, Ross et al., 2009). Despite that, some of the characteristics of these sites may draw attention of them. Self-controlled individuals mainly prefer direct-messaging in social networking sites and they strictly limit their personal information that can be seen by others (Muscanel and Gudagno, 2012). About the posts that they believe to be inappropriate, they significantly feel the remorse (Moore and McElroy, 2012). These individuals are seen to use social networking sites for academic purposes rather than spending free time and entertainment (McElroy, Hendrickson, Townsend and DeMarie 2007).

$\mathrm{Np}$ relationship was found between adolescents' use of Facebook and their openness for improvement. Given the studies examining the relationship with use of Facebook, it can be seen that openness for improvement is both an important (Correa et al., 2010; Hughes et al., 2012; McElroy et al., 2007; Seidman, 2013) and unimportant (Moore and McElroy, 2012) factor for both the frequency of using Facebook. Considering from the contextual aspect, it can be seen that the individuals that are open to development do not significantly prefer messaging in Facebook but sending posts on the walls of others (Ross et al., 2009), sharing personal information and using Facebook for communicating with others (Amichai, Hamburger and Vinitzky, 2010). Besides that, by using Facebook for following what the others are doing, they maintain their interaction with real life (Carpenter, Green and LaFlam, 2011). On the other hand, there are studies reporting that openmindedness is not an important factor for searching for information, speaking, and opening oneself in Facebook (Seidman, 2013).

No relationship was found between adolescents' use of Facebook with their tendermindedness. The relationship of tendermindedness with the use of Facebook has been subjected to various studies. It can be seen in the findings of those studies that adaptability is not an important factor for the use of Facebook (Bachrach, Kosinski, Graepel, Kohli and Stillwell, 2012; Ross et al., 2009). But, the tenderminded users of Facebook use it for explaining personal truths and communicating rather than drawing attention or gathering information (Seidman, 2013). Moreover, while these users avoid from sharing posts with others through Facebook, they share 
Bilgin, M., Yilmaz, A. (2017). The relationship between social network usage and some personality traits. Journal of Human Sciences, 14(3), 2219-2243. doi:10.14687/jhs.v14i3.4659

relatively more posts about themselves (Moore and McElroy, 2012). Although having personality trait of tendermindedness is not an important factor for having more friends in Facebook (Amichai, Hamburger and Vinitzky, 2010), it can be seen that the friends of these individuals send positive feedbacks for their posts (Wang et al., 2012).

Statistically significant differences were found between the use of "Twitter" and tendermindedness, self-control, openness for improvement and extroversion. Negative relationship was found between the Twitter accounts and tendermindedness and self-control, while negative relationships were found with openness for improvement and extroversion. Hughes, Rowe, Batey and Lee (2012) found positive relationship between Twitter and openness for improvement and negative relationship with extroversion and self-control and nonsignificant difference with neuroticism. In study of Rowe et al., negative relationship with extroversion and no relationship with neuroticism were found, and this result is in corroboration with ours. The individuals having high level of tendermindedness can easily adapt to what the others say and want (Howard and Howard, 1998). For this reason, the tenderminded individuals may frequently use Twitter for following the thoughts and opinions shared by others.

Quercia, Kosinski, Stillwell and Crowcroft (2011) found that the Twitter users having high number of followers are more extroversive. Dal and Dal (2014) found that the openness for improvement scores of Twitter members were higher than those of individuals, who have no Twitter membership. The results of other studies are not in corroboration with our findings. In this study, negative relationship was found between use of Twitter and openness for improvement and extroversion. Extroversion is related with the number of people around persons and the individual's mood and relationship quality in a group. The level of extroversion of an individual feeling comfortable and enjoying being a crowded environment is high. The individuals having low level of extroversion are those being in relation with limited number of person, not enjoying being in such an environment, and feeling themselves uncomfortable in those environments (Howard and Howard, 1998). Accordingly, highly extroversive persons might not consider Twitter as a socialization tool since they prefer face-to-face socialization.

Statistically significant differences were found between the use of "Google+" and openness for improvement. There is a negative relationship between "Google+", which is one of the social networks used by adolescents, and openness for improvement. Dal and Dal (2014) determined that the extroversion score of those having membership to Google+ was higher than that of those having no membership. The persons with personal trait of openness for improvement, who enjoy trying new things, may try using Google+ and then prefer new, different, and more efficient applications.

Statistically significant differences were found between the use of "YouTube" and selfcontrol, openness for improvement and extroversion. There are positive relationship between "YouTube", which is one of the social networks used by adolescents, and self-control and negative relationship with openness for improvement and extroversion.

Biel, Aran and Perez (2011) found significant relationship between the use of YouTube and the personality traits of extroversion, openness for improvement and self-control. The findings of this study are in corroboration with our results. The self-controlled individuals are tidy, selfregulated, and success-oriented persons. These individuals may use YouTube because they earn money by regularly sharing videos. The individuals, who are open for improvement, may prefer using YouTube for following what others do rather than actively using it. For extroversive persons, YouTube may not be considered as an alternative to face-to-face conversation. Dal and Dal (2014) determined the emotional balance scores of YouTube users to be higher than that of those having no YouTube membership. In present study, no relationship was found between the use of YouTube and the neuroticism.

Statistically significant differences were found between the use of "Instagram" and the personality traits of self-control, neuroticism, openness for improvement, and extroversion. 
Bilgin, M., Yilmaz, A. (2017). The relationship between social network usage and some personality traits. Journal of Human Sciences, 14(3), 2219-2243. doi:10.14687/ihs.v14i3.4659

Positive relationship was found between "Instagram", which is one of the social networks used by adolescents, and self-control, while negative relationship was found with personality traits of neuroticism, openness for improvement, and extroversion. The self-controlled individuals, who are known for being controlled and prudent, use Instagram for sharing photos in moderation. They might know that spending more time in Instagram would be waste of time. The reason for low level of use of Instagram by neurotic individuals having sceptic, anxious, and vulnerable characters may be to avoid from giving reactions such as sorrowing for nothing or making something out of nothing. Any photo or message that is shared may increase the level of anxiousness of a neurotic individual. The individuals, who are open for improvement and who appreciate interaction with others and seek for novelty in their lives, may prefer the interaction in social life. Thus, they might not prefer using social media. The extroversive individuals enjoying spending time with others and not wanting to be alone might think that Instagram constructs fake friendships. One of the reasons for less frequently using Instagram, which doesn't establish permanent friendships, might be that it is an application that doesn't guarantee the quality of interpersonal relationship.

Statistically significant differences were found between the use of "Foursquare" and tendermindedness, self-control, neuroticism and extroversion among the Five-Factor personality traits. Positive relationship was found between "Foursquare", which is one of the social networks used by adolescents, and tendermindedness and self-control, while negative relationship was found with neuroticism and extroversion. There is a positive correlation between visited locations and self-control. Moreover, there is also a negative relationship with neuroticism. On the contrary with expectations, there is a positive correlation between the openness for improvement and the visited locations (Chorley, Colombo, Allen, and Whitaker, 2013). The findings of this study are not in corroboration with our findings. The tenderminded individuals use Foursquare for following the locations, which are visited by the friends at most, and for communication. Since the neurotic individuals are anxious persons, they may not want to use it, because their anxiousness level regarding the visibility of locations they visited would increase. The extroversive individuals are those directing their spiritual energy to outer world. They have friendly, sincere, open-for-change, and adaptable character. They enjoy the movement, and need for persons near them. Silence and loneliness are not appropriate for them. Since they constantly change location, they might think that posting the locations may disturb the others.

Statistically significant differences were found between the use of "Vine" and tendermindedness, self-control, openness for improvement and extroversion. Positive relationship was found between "Vine", which is one of the social networks used by adolescents, and tendermindedness and self-control, while negative relationship was found with openness for improvement and extroversion.

Since the persons having self-control trait are those having sense of mission and not wanting to waste time, they may use Vine app because of its advantage of 6sec. videos. The tenderminded individuals having a passive structure and avoiding from arguing with others may not find sharing videos in Vine inconvenient since they are modest, sensitive, and deliberate persons. The reason for negative relationship with openness for improvement and extroversion is based on the sarcastic communications between the people in Vine community.

Statistically significant differences were found between the use of "BlogSpot" and tendermindedness and self-control. There is positive relationship between "BlogSpot", which is one of the social networks used by adolescents, and tendermindedness and self-control. Dal and Dal (2014) determined significant differences between those having BlogSpot membership and those no membership in terms of neuroticism and openness for improvement. In this study, no relationship was found between the adolescents' use of BlogSpot and their neuroticism and openness for improvement. Self-controlled individuals exhibiting responsible and generally deliberate behaviors can meet the tidiness and responsibility requirements of blogging more easily. 
Bilgin, M., Yilmaz, A. (2017). The relationship between social network usage and some personality traits. Journal of Human Sciences, 14(3), 2219-2243. doi:10.14687/jhs.v14i3.4659

Since the tenderminded persons pay importance to social cooperation, they can reach at higher number of readers by writing blogs.

Statistically significant differences were found between the use of "Tumblr" and personality traits of tendermindedness, self-control, openness for improvement, and extroversion. "Tumblr", which is one of the social networks used by adolescents, was found to have positive relationship with tendermindedness and self-control and negative relationship with openness for improvement and extroversion. Since Tumblr and BlogSpot are similar applications, the results regarding selfcontrol and tendermindedness were found to be similar. Unlike BlogSpot, the Tumblr application is easier-to-use and it doesn't require any specific attention, thus it may not be appropriate for extroversive persons and those open to improvement.

Statistically significant differences were found between the use of "Pinterest" and personality traits of self-control and openness for improvement. "Pinterest", which is one of the social networks used by adolescents, has positive relationship with self-control and negative relationship with openness for improvement. Self-controlled individuals may prefer using Pinterest because of its user-friendly nature since it distinguishes certain categories. The persons that are open for improvement may prefer using it less frequently because of the category limitation of Pinterest.

Statistically significant differences were found between the use of "Skype" and personality traits of self-control, openness for improvement and extroversion. "Skype", which is one of the social networks used by adolescents, was found to have positive relationship with self-control and negative relationship with extroversion and openness for improvement. The use of Skype by teachers in group studies during educational activities may allow self-controlled individuals to participate into group works. Since extroversive individuals are active in outer world, they may prefer using it less because of the deficiency of Skype in hands-free communication.

Statistically significant differences were found between the use of "Whats App" and personality traits of self-control, openness for improvement and extroversion. "Whats $A p p$ ", which is one of the social networks used by adolescents, was found to be in positive relationship with selfcontrol and negative relationship with extroversion and openness for improvement. Extroversion is very important in understanding the use of WhatsApp. When compared to others, the individuals that have been using smart phones from earlier periods use WhatsApp for longer durations (Montag, 2014). According to Sultan (2014), extroversive individuals exhibit more positive attitudes towards the use of WhatsApp. The positive correlation between the use of WhatsApp and the neuroticism was found to be very low. In study of Correa, Hinsley and Zuniga (2010), it was determined that the individuals with high level of neuroticism were found to be prone to use Facebook facilitating the communication without face-to-face conversation. Finally, negative relationship was found between the self-control and the use of WhatsApp. The results of previous studies are not in corroboration with those of present study. Self-controlled individuals may be using WhatsApp since they feel it compulsory to answer the messages sent via this application. Since messaging is a more traditional application, the individuals open for improvement may not prefer using it. Extroversive persons are enthusiastic about befriending, thus they may find WhatsApp boring.

\section{CONCLUSIONS and SUGGESTIONS}

There is a negative relationship between self-control and hours of using social networks. As the duration of using social networks, the self-control decreases. Besides that, no statistically significant difference was found between the openness for improvement and the tendermindedness. Duration of using social networks is positively related with neuroticism and extroversion. In other words, the extroversion and neuroticism increase as the duration of using social networks increases. 
Bilgin, M., Yilmaz, A. (2017). The relationship between social network usage and some personality traits. Journal of Human Sciences, 14(3), 2219-2243. doi:10.14687/jhs.v14i3.4659

Positively significant difference was found between the self-control and the purpose of "baving new friends" for adolescents' use of social media. The purpose of "online chatting" has positive relationship with tendermindedness and self-control and negative relationship with extroversion. The purpose of "sharing photos" is negatively related with neuroticism and extroversion. Positively significant difference was found between the purpose of "commenting" and the self-control, while negatively significant difference was found with extroversion. The negatively significant difference was found between the purpose of "accessing to information" and the self-control and extroversion, while positively significant difference was found with openness for improvement. Positively significant difference was found between the purpose of "sharing video" and the self-control, while negatively significant difference was found with extroversion. Negatively significant difference was found between the purpose of "sharing news" and the openness for improvement, while positively significant difference was found with extroversion. Negatively significant difference was found between the purpose of "communicating with friends" tendermindedness and extroversion. Positively significant difference was found between the purpose of "checking what the friends do" and the tendermindedness and self-control, while negatively significant difference was found with neuroticism and extroversion. Positively significant difference was found between the purpose of "recreation" and the self-control, while negatively significant difference was found with neuroticism and extroversion.

Positively significant difference was found between "Facebook", which is one of the social networks used by adolescents, and neuroticism. Positively significant difference was found between the use of "Twitter" and the tendermindedness and self-control, while negatively significant difference was found with extroversion and openness for improvement. Negatively significant difference was found between the use of "Google+" and the openness for improvement. Positively significant difference was found between the use of "YouTube" and the self-control, while negatively significant difference was found with extroversion and openness for improvement. Positively significant difference was found between the use of "Instagram" and the self-control, while negatively significant difference was found with extroversion and openness for improvement. Positively significant difference was found between the use of "Foursquare" and the tendermindedness and self-control, while negatively significant difference was found with extroversion and neuroticism. Positively significant difference was found between the use of "Vine" and the tendermindedness and self-control, while negatively significant difference was found with extroversion and openness for improvement. Positively significant difference was found between the use of "BlogSpot" and the tendermindedness and self-control. Positively significant difference was found between the use of "Tumblr" and the tendermindedness and self-control, while negatively significant difference was found with extroversion and openness for improvement. Positively significant difference was found between the use of "Twitter" and the tendermindedness and self-control, while negatively significant difference was found with extroversion and openness for improvement. Positively significant difference was found between the use of "Pinterest" and the self-control, while negatively significant difference was found with openness for improvement. Positively significant difference was found between the use of "Skype" and the self-control, while negatively significant difference was found with extroversion and openness for improvement. Positively significant difference was found between the use of "Whats $A p p$ " and the self-control, while negatively significant difference was found with extroversion and openness for improvement.

This study is limited to the social networking websites that are actually being used by adolescents. Other social networking websites can be investigated in further studies. The present study was carried out on adolescent sample. The relationship of the use of social media with the Five Factor personality traits can also be investigated from the aspect of different age groups. While examining the relationship of the use of social media with the Five Factor personality traits, different parameters such as adolescents' life satisfaction and their psychological needs can also be studied. Since this study was carried out with secondary school and elementary school students, the 
Bilgin, M., Yilmaz, A. (2017). The relationship between social network usage and some personality traits. Journal of Human Sciences, 14(3), 2219-2243. doi:10.14687/ihs.v14i3.4659

difference can be revealed by implementing the tests on older individuals such as university students. As an extension of this study, the qualitative studies are needed for learning about the students' use of social media.

\section{References}

Ahn, J. (2011). Digital divides and social network sites: Which students participate in social media? J. Educational Computing Research, 45(2) 147-163.

Akca Baştürk, E. (2014). Dijital bölünme kavramı bağlamınsa Türkiye'de ortaokul öğrencilerinin internet ve sosyal ağ kullanımları: Gaziantep İli Örneği. I. Uluslararası İletişim Bilimi ve Medya Arasturmalar Kongresi. Kocaeli.

Akyazı, E. ve Tutgun-Ünal, A. (2013). İletişim fakültesi öğrencilerinin amaç, benimseme, yalnızlık düzeyi ilişkisi bağlamında sosyal ağları kullanımı. Global Media Journal TR, 3(6), 1-24.

Alican, C. ve Saban, A. (2013). Ortaokul ve lisede öğrenim gören öğrencilerin sosyal medya kullanımına ilişkin tutumları: Ürgüp örneği. Sosyal Bilimler Enstitïsü Dergisi, 35(2), 1-14.

Amichai-Hamburger, Y. \& Vinitzky, G. (2010). Social network use and personality. Computers in Human Behavior, 26, 1289-1295.

Amichai-Hamburger, Y., Wainapel, G. ve Fox, S. (2002). "On the Internet no one knows I'm an introvert": Extroversion, neuroticism, and Internet interaction. Cyberpsychology \& Behavior, 5, 125-128.

Amiel, T. ve Sargent, S. (2004). Individual differences in Internet usage motives. Computers in Human Behavior, 20(6), 711-726.

Bachrach, Y., Kosinski, M., Graepel, T., Kohli, P. ve Stillwell, D. (2012, Haziran). Personality and patterns of Facebook usage. In Proceedings of the 4th Annual ACM Web Science Conference (s. 24-32). ACM.

Balaman, F ve Karataş, A. (2012). Lise Öğrencilerinin İnternet Ortamında Sosyal Paylaşım Sitelerini Kullanım Amaçları ve Sosyal Paylaşım Unsurları. Batman Üniversitesi Yaşam Bilimleri Dergisi, 1(1), 497-504.

Bat, M. ve Vural, B.A. (2010). Yeni bir iletişim ortamı olarak sosyal medya: Ege Üniversitesi iletişim fakültesine yönelik bir araştırma. Journal of Yasar University. 20(5) 3348-3382.

Bayhan, V. (2011). Lise öğrencilerinde internet kullanma alışkanlığı ve internet bağımlılı̆̆1 (Malatya uygulamas1). Akademik Bilisim'11 - XIII. Akademik Bilisim Konferansı Bildirileri (s. 237-244), İnönü Üniversitesi, Malatya, 2-4 Şubat.

Biel, J.I., Aran O., Perez, D.G. (2011). You are Known by how you vlog. Personality and nonverbal behavior in youtube. Proceedings of the Fifth International AAAI Conference on Weblogs and Social Media

Bonetti, L., Campbell, M. A. ve Gilmore, L. (2010). The Relationship of Loneliness and Social Anxiety with Children's and Adolescents' Online Communication. Cyberpsychology, Behavior, and Social Networking, 13(3), 279-285.

Boyd, D.M., \& Ellison, N. B. (2007). "Social network sites: Definition, history, and scholarship." Journal of Computer-Mediated Communication, 13(1).

Buckner, J.E., Castille, C.M., and Sheets, T.L. (2012). The Big Five Factor Model of Personality and Employee" Excessive Use of Technology. Computers in Human Behavior, 28, 1947-1953.

Burger, J. M. (2006). Kişilik. (çev. İ. D. Erguvan Sarığlu). İstanbul: Kaknüs Yayıncilık.

Butt, S. ve Phillips, J. G. (2008). Personality and self reported mobile phone use. Computers in Human Behavior, 24(2), 346-360.

Büyüköztürk, Ş., Çakmak, K, E., Akgün, E, Ö., Demirel, F., \& Karadeniz, Ş. (2008). Bilimsel arasstrma yöntemleri. Ankara: Pegem Akademi.

Carpenter, J. M., Green, M. C. ve LaFlam, J. (2011). People or profiles: Individual differences in online social networking use. Personality and Individual Differences, 50, 538-541. 
Bilgin, M., Yilmaz, A. (2017). The relationship between social network usage and some personality traits. Journal of Human Sciences, 14(3), 2219-2243. doi:10.14687/jhs.v14i3.4659

Chorley, M. J., Colombo, G. B., Allen, S. M., \& Whitaker, R. M. (2013). Visiting patterns and personality of foursquare users. Proceedings - 2013 IEEE 3rd International Conference on Cloud and Green Computing, CGC 2013 and 2013 IEEE 3rd International Conference on Social Computing and Its Applications, SCA 2013, 271-276. http://doi.org/10.1109/CGC.2013.50

Correa, T., Hinsley, A. W. ve Zuniga, H. G. (2010). Who interacts on the web? The intersection of users' personality and social media use. Computers in Human Behavior, 26, 247-253.

Cüceloğlu, D. (2011). Insan ve davranıs psikolojinin temel kavramlar. Remzi Kitapevi, Yirmi İkinci Bask1, İstanbul.

Dal, N. E. ve Dal, V. (2014). Kişilik özellikleri ve sosyal ağ sitesi kullanım alışkanlıkları : Üniversite öğrencileri üzerine bir araştırma. Mehmet Akif Ersoy Üniversitesi. Sosyal Bilimler Enstitüsü Dergisi. 6(11).

Davies, T. ve Cranston, P. (2008). Youth work and social networking. Interim report, May, 2008. The National Youth Agency: Leicester, UK.

Deniz, A. (2012). Sosyal ăg kullanım ve sosyal ağlarda benlik algısı: Muğla ili ömeği. Yayınlanmamış yüksek lisans tezi. Ege Üniversitesi, İzmir.

Fossati, A., Borroni,S., Marchione, D. \& Maffei, C. (2011). The Big Five Inventory(BFI) Reliability and Validity of its Italian Translation in Three Independent Nonclinical Samples. European Journal of Psychological Assessment, 27 (1), 50-58.

Gençlik ve Spor Bakanlığı. (2013). Gençlik ve Sosyal Medya Araştırma Raporu. Ekim.

Glass, R., Prichard, J., Lafortune, A., and Schwab, N. (2013). The Influence Of Personality and Facebook Use On Student Academic Performance. Issues in Information Systems, 14(2), 119126.

Gosling, S. D., Augustine A.A., Vazire S., Holtzman, N., and Gaddis, S. (2011). "Manifestations of Personality in Online Social Network: Self-Reported Facebook-Related Behaviors and Observable Profile Information", Cyberpsychology, Behavior, And Social Networking, 14, 9.

Gross, E.F. (2004) Adolescent internet use: What we expect, what teens report. [Çevrimiçi sürüm]. Applied Developmental Psychology, 25, 633-649.

Hazar, M. (2011). Sosyal medya bağımlılı̆̆ı: bir alan çalışması. İletişim Kuram ve Araştırma Dergisi, 3, $158-159$.

Howard P.J. ve Jane M. Howard (1998). The Big Five Quickstart an Introduction To The Five Factor Model of Personality For Human Resource Professionals.

Hughes, D. J., Rowe, M., Batey, M. \& Lee, A. (2012). A tale of two site: Twitter v: Facebook and the personality predictors of social media usage. Computers in Human Behavior, 28, 561-569.

John, O.P., \& Srivastava, S. (1999). The Big Five trait taxonomy: History, measurement and theoretical perspectives. In L.A. Pervin \& O.P. John (Eds.), Handbook of personality: Theory and research, 102-138. New York: Guilford.

Karaduman, M. ve Kurt, H. (2010, Aralık). İletişim fakültesi ögrencilerinin sosyal medyay kullanım dü̈reyleri. XV. Türkiye'de İnternet Konferansinda sunulan bildiri. İstanbul Teknik Üniversitesi, İstanbul.

Kim, H.K. ve Davis, K.E. (2009). Toward a comprehensive theory of problematic internet use: Evaluating the role of self-esteem, anxiety, flow, and the self-rated importance of internet activities. [Çevrimiçi sürüm]. Computers in Human Behavior, 25, 490-500.

Lenhart, A., ve Madden, M. (2007). Social networking websites and teens: An overview (p. 10). Pew/Internet.

Lenhart, A., Purcell, K., Smith, A. ve Zickuhr, K. (2010). Social media \& mobile internet uses among teens and young adults. Pew Internet \& American Life Project, An initiative of the Pew Researh Center, Washington, D.C.

Lin, M.F.G., Hoffman, E.S. ve Borengasser, C. (2013). Is social media too social for class? A case study of Twitter use. TechTrends, 57(2), 39-45. 
Bilgin, M., Yilmaz, A. (2017). The relationship between social network usage and some personality traits. Journal of Human Sciences, 14(3), 2219-2243. doi:10.14687/ihs.v14i3.4659

Livingstone, S. (2008). Taking risky opportunities in youthful content creation: Teenagers' use of social networking sites for intimacy, privacy and self-expression. New Media Soc., 10, 393411.

McCrae, R.R. „\& Costa, P.T.(2006). Personality In Adulthood, A Five-Factor Theory Perspective. Second Edition, Guilford Press, New York.

McElroy, J., Hendrickson, A., Townsend, A. ve DeMarie, S. (2007). Dispositional factors in Internet use: Personality versus cognitive style. MIS Quarterly, 31(4), 809-820.

Mehdizadeh, S. (2010). Self-presentation 2.0: narcissism and self-esteem on Facebook. Cyberpsychol Behav Soc Netw 13(4):357-64.

Montag, C., Błaszkiewicz. K., Lachmann, B., Andone, I, Sariyska, R., Trendafilov, B., Reuter, M., Markowetz, A. (2014) Correlating personality and actual phone usage: evidence from psychoinformatics. J Individ Differ, 35, 158-165.

Moore, K. ve McElroy, J. C. (2012). The influence of personality on Facebook usage, wall postings, and regret. Computers in Human Behavior, 28, 267-274.

Mumtaz, S.. (2001). Children's enjoyment and perception of computer use in the home and the school. [Çevrimiçi sürüm]. Computers \& Education, 36, 347-362.

Muscanell, N. L. ve Guadagno, R. E. (2012). Make new friends or keep the old: Gender and personality differences in social networking use. Computers in Human Behavior, 28, 107-112.

Ong, E. Y. L., Ang, R. P., Ho, J. C. M., Lim, J. C. Y., Goh, D. H., ve Lee, C. S. (2011). Narcissism, extraversion and adolescents' self-presentation on Facebook. Personality and Individual Differences, 50(2), 180-185.

Otrar, M. ve Argın, F. S. (2014). Öğrencilerin Sosyal Medyaya İlişkin Tutumlarının Kulanım Alışkanlıkları Bağlamında İncelenmesi. Eğitim Ve Öğretim Arastırmalar Dergisi, 3(3).

Ök, F. (2013). Ortaögretim ögrencilerinin sosyal medya kullanm alsskanllklar ve motivasyonlar. Yayınlanmamış yüksek lisans tezi. Fırat Üniversitesi, Elazığ.

Özmen, F., Aküzüm, C., Sünkür, M. ve Baysal, N. (2011). Sosyal Ağ Sitelerinin Eğitsel Ortamlardaki Işlevselliği. 6th International Advanced Technologies Symposium (LATS'11), 16-18 May 2011, Elazı̆, Turkey.

Park, C.H. ve Kim, Y.J. (2013). Intensity of social network use by involvement: A study of young Chinese users. International Journal of Business and Management, 8(6), 22-33.

Pempek, T. A., Yermolayeva, Y. A. ve Calvert, S.L. (2009). College students' social networking experiences on Facebook. Journal of Applied Developmental Psychology, 30, 227-238.

Quercia, D., Kosinski, M., Stillwell, D., \& Crowcroft, J. (2011). "Our Twitter Profiles, Our Selves: Predicting Personality with Twitter”, In Privacy, Security, Risk and Trust (PASSAT), 2011 IEEE Third International.

Roccas, S., Sagiv, L., Schwartz, S.H. ve Knafo, A.(2002). The Big Five Personality Factors and Personal Values. Personality and Social Psychology Bulletin, 28, 789-801.

Ross, C., Orr, E. S., Sisic, M., Arseneault, J. M., Simmering, M. G. \& Orr, R. R. (2009). Personality and motivations associated with Facebook use. Computers in Human Behavior, 25, 578-586.

Ryan, T. ve Xenos, S. (2011). Who uses Facebook? An investigation into the relationship between the Big Five, shyness, narcissism, loneliness, and Facebook usage. Computers in Human Behavior. 27, 1658-1664.

Schmitt, D. P., Allik, J., McCrae, R. R. ve Benet-Martinez, V. (2007). The geographic distribution of big fi ve personality traits: Patterns and profi les of human self-description across 56 nations. Journal of Cross-Cultural Psychology, 38 (2), 173-212.

Seidman, G. (2013). Self-presentation and belonging on Facebook: How personality influences social media use and motivation. Personality and Individual Differences, 54, 402-407.

Somer, O. (1998). Türkçe'de kişilik özelliği tanımlayan sıfatların yapısı ve beş faktör modeli. Türk Psikoloji Dergisi, 13 (42), 17-32. 
Bilgin, M., Yilmaz, A. (2017). The relationship between social network usage and some personality traits. Journal of Human Sciences, 14(3), 2219-2243. doi:10.14687/jhs.v14i3.4659

Subrahmanyam, K. \& Greenfield, P. (2008). Communicating Online: Adolescent Relationships and the Media. The Future of Children, 18 (1). 1-27.

Subrahmanyam, K., Reich, S. M., Waechter, N. \& Espinoza, G. (2008). Online and offline social networks: Use of social networking sites by emerging adults. Journal of Applied Developmental Psychology, 29, 420-433.

Sultan A.J. (2014) Addiction to mobile text messaging applications is nothing to "lol" about. Soc Sci J, 51, 57-69.

Sümer, N., Lajunen, T. ve Özkan, T. (2005). Big fi ve personality traits as the distal predictors of road accident involvement. G. Underwood, (Ed.), Traffic and transport psychology. Elsevier Ltd. 215-217.

Şener, G. (2009). Türkiye'de Facebook kullanm arastırması. 14. Türkiye'de İnternet Konferansinda Sunulan Bildirileri. Bilgi Üniversitesi, İstanbul.

Tanrıverdi, H. ve Sağır, S. (2014). Lise öğrencilerinin sosyal ağ kullanım amaçlarının ve sosyal ağları benimseme düzeylerinin öğrenci başarısına etkisi. Adiyaman Üniversitesi Sosyal Bilimler Enstitüsü Dergisi, 7(18), 775-822.

Tutar, H. (2013). Davranıs bilimleri kavramlar ve kuramlar. Seçkin Yayıncılık, Birinci Bask1, Ankara.

Tutgun-Ünal, A. ve Köroğlu, O. (2013). A comparative study of social network usage and adoption among Turkish prospective teachers. Mevlana International Journal of Education (MIJE), 3(4), 24-42.

UBİK (2011) "Çocuklarm Sosyal Paylașım Sitelerini Kullanm Aluskeanlkklar Araștırması Raporu" Http:/ /Www.İternetkurulu.Org/Tr/Raporlar.Aspx (Erişim Tarihi: 20 Ocak 2016)

Valkenburg, P.M. \& Peter, J. (2007). Preadolescents' and adolescents' online communication and their closeness to friends. [Çevrimiçi sürüm]. Developmental Psychology, 43(2), 267-277.

Wang, J.L., Jackson, L.A., Zhang, D.J., ve Su, Z.Q. (2012). The relationships among the Big Five Personality factors, self-esteem, narcissism, and sensation- seeking to Chinese University students" uses of social networking sites (SNSs). Computers in Human Bebavior.28, 23132319.

Wehrli, S. (2008). "Personality on Social Network Site: An Application of the Five Factor Model, ETH Zurich Sociology Working Paper No. 7, September, 5.

Wilson, K., Fornasier, S., \& White, K.M. (2010). Psychological predictors of young adults' use of social networking sites. CyberPsychology, Bebavior \& Social Networking, 13(2), 173-177.

Yıldırım, N. ve Özmen, B. (2011). "Video Paylaşım Sitelerinin Eğitsel Amaçlı Kullanımı" 5th International Computer \& Instructional Technologies Symposium, 22-24 September, Firat University, Elazığ. 